\title{
Energy, Exergy-Based and Emergy-Based Analysis of Integrated Solar PTC with a Combined Cycle Power Plant
}

\author{
M. Hajizadeh Aghdam ${ }^{1}$, N. Khani ${ }^{1,2}$, M. Khoshgoftar Manesh ${ }^{1 *}$, M. Yazdi ${ }^{2}$ \\ ${ }^{1}$ Energy, Environmental and Biological Systems Research Lab (EEBRlab), Division of Thermal Sciences and Energy \\ Systems, Department of Mechanical Engineering, Faculty of Technology \& Engineering, University of Qom, Qom, Iran \\ ${ }^{2}$ Center of Environmental Research, Qom, Iran. \\ Email: m.khoshgoftar@qom.ac.ir; mh.khoshgoftar@gmail.com
}

Received 24 March 2021, Revised 3 July 2021, Accepted 26 July 2021

\begin{abstract}
Solar energy is one of the most promising strategies to reduce energy consumption and emissions pollutions. In this paper, integrating a combined cycle power plant with a Solar Parabolic Trough Collector (PTC) is evaluated and investigated. In this regard, Qom Combined Cycle Power Plant is considered a real case study in Qom city. Energy, Exergy, Exergoeconomic, Exergoenvironment, Emergoeconomic, and Emergoenvironemntal Analysis as (6E) Analysis have been performed to understand the base plant's integration better. Environmental impacts have been calculated by Life Cycle Assessment (LCA) in Sima Pro Software. Also, computer code has been developed for 6E analysis of base and integrated power plants. Validation of thermodynamic simulation has been examined with Thermoflex Software and plant data. Energy analysis results show the power output of the steam plant and overall energy efficiency is increased to $7.14 \%$ and $4.44 \%$ rather than the base case without adding additional fossil fuel. It shows the power generation and energy efficiency are increased significantly by adding PTC. Also, the overall exergy destruction and the total exergy cost rates are raised to $7 \%$ and $11.27 \%$. In addition, overall environmental impacts, overall emergoeconomic, and overall emergoenvironmental values are increased to $1.67 \%, 6.2 \%$, and $15.4 \%$, respectively. However, the overall environmental impacts per net power are decreased.
\end{abstract}

Keywords: 6E Analysis; solar PTC; combined cycle; integrated.

\section{Introduction}

A marked increase in the population, careless use of traditional fuels accompanies by the greenhouse effect, and water scarcity are giving cause for concern. Nowadays, Iran is dealing with water shortage which requires developed technology utilization not only to supply fresh water but also to exploit power plants waste heat, and overcome emissions. Integration power plant with a desalination unit would be a practical and effective approach in coming years.

Seoung et al. (2016) made an attempt to assess energy cost between the combination of multi-stage flash (MSF), multi-effect distillation (MED), and reverse osmosis (RO) with a simple cycle oil-fired power plant (OFPP) and a combined-cycle power plant. It was derived that thermal desalination leads to obtain more benefits compare to the combined cycle's higher efficiency. The highest production of power and water with the aid of the developed mathematical model was accomplished [1].

A developed R-Curve methodology for water power cogeneration plants was proposed by Salimi and Amidpour (2017). Their proposed cycle was analyzed from exergy and exrgoeconomic point of view, and a decline from 2.8 to 2.3 $\$ / \mathrm{m}^{3}$ in the final total cost of the produced potable water was demonstrated [2]. Hosseini et al. (2012) considered integrating a combined-cycle power plant with an MSF unit to gain an economic, exergetic, environmental, and reliable optimization. They achieved a product and environmental cost reduction of $13.4 \%$ and $53.4 \%$, respectively.
Nevertheless, the overall exergy efficiency goes up by $14.8 \%$, relative to the base case study [3].

Besides power plant and desalination unit integration, some studied the hybrid power plants with solid oxide fuel cells (SOFC) and water production systems. An optimum exergoeconomic design of a GT-SOFC-MED integrated plant employing a genetic algorithm was disclosed by Ahmadi et al. (2018). The results showed that energy consumption and pollution of the power generation cycle was fallen as a consequence of water and electricity production at the same time [4]. Moreover, a SOFC-micro gas turbine was incorporated into a MED unit by Hosseini [5]. This study depicted that the capacity of the cogeneration plant and the energy efficiency enhancement are considerably affected by the fuel cell stack pressure. Likewise, by increasing the steam pressure, the steam mass flow rate goes down, and the capacity of the desalination unit goes up. Najafi et al. tried an exergetic optimization of a coupled gas turbine-MSF-SOFC. An optimum exergetic efficiency and an overall annual cost of about $46.7 \%$ and 3.76 million \$/year were concluded, respectively [6].

and organic cycles. Integrating a MED desalination unit by a combined-cycle dual-purpose plant was estimated by Chacartegui et al. (2009). They utilized the stationary lumped volume approach and reported different numerical and qualitative results to combine the combined cycle with desalinated water production [7]. Li et al. (2012) studied an innovative hybrid of power and desalination units. The properties of the compressor's inlet air influence the 
performance of the cycle in many ways [8]. DeymiDashtebayaz et al. considered energy, exergy, economic and environmental points of view. The authors noted that absorption chiller, in addition to the best performance for the cooling of the inlet air, causes thermal and exergy efficiency improvement [9].Abdalisousan et al. optimized some thermodynamic properties of a combined cycle power plant considering economic and exergy efficiency. They noted that using this optimization, the cost of production per unit of output goes down about $2 \%$, and the exergy efficiency goes up by $4 \%$ [10].

Zhang et al. evaluated the techno-economic analysis of integrating coal-fired power plants by a $\mathrm{CO}_{2}$ capture system. The consequences indicate that a pre-combustion $\mathrm{CO}_{2}$ capture system captures more carbon dioxide with a lower capital cost and energy penalties. The proposed system operates with a supercritical organic Rankine cycle as a working fluid (SORC), an ejector, and a MED unit to produce freshwater. Eventually, a $40 \%$ gain in overall exergetic efficiency for $35 \mathrm{~g} / \mathrm{kg}$ of saline water and lowgrade heat at $150^{\circ} \mathrm{C}$ and no demand for additional energy input for brine as much as $55 \mathrm{~g} / \mathrm{kg}$ salt concentration was pointed out [11]. A cogeneration system based on a combination of chemically-recuperated gas turbine cycle with thermal desalination is introduced by Chending Luo et al. (2014). They observed that the steam turbine combined cycle results in a more economical unit compared to a combined cycle consisting of a MED/MSF.

Chiang et al. studied a combined cycle power plant (CCPP) to overcome electric shortages during the summer, including an overspray inlet fogging system into an existing gas turbine under various ambient conditions. The work showed that the CCPP net power enhancement is subject to the percentage of overspray under site average ambient conditions [12]. Khanmohammadi utilized IPSE Pro to simulate a combined-cycle power plant (CCPP) consisting of supplementary firing. They made exergy, and exergoeconomic investigations and the effect of three configurations of a heat recovery steam generator (HRSG) and performance parameters have been demonstrated. As a result, the cost of output power for the three configurations of CCPP and the best location for the duct burner in HRSG was reported [13].

An energetic and exergetic evaluation has been conducted for a combined cycle with and without supplementary firing by Logof. The authors derived that the combined cycle (CC) with supplementary firing leads to $12.2 \%$ and $2.07 \%$ augmentation in the generated power and efficiency of the heat recovery steam generator; respectively, by contrast, the thermal efficiency of the combined cycle caused $1.4 \%$ reduction [14].

Calise carried out a dynamic model of a high-temperature integrated solar combined cycle power plant for thermoeconomic and environmental evaluation. The extra cost of the solar part is recovered in about 15 years. However, a parametric analysis showed that the smallest solar field area should be considered [15]. Baghernejad evaluated an Integrated Solar Combined Cycle System (ISCCS) employing exergoeconomic principles and genetic algorithm. This study aims to minimize the investment cost of equipment and the cost of exergy destruction. About $11 \%$ reduction in total cost was reported. Also, the optimization result showed that the expense of electricity produced by the steam turbine and gas turbine of the ISCCS decreased about
$7.1 \%$ and $1.17 \% .13 .3 \%$ enhancement in capital investment demonstrated to meet these objectives [16].

Implement a multi-objective strategy to optimize a Gas Turbine-Modular Helium Reactor (GT-MHR) integrated with two Organic Rankine Cycles (ORCs) from both thermodynamic and economic points of view was investigated by Keyvan Bahlouli. The exergy efficiency reaches $50.20 \%$ for the optimized condition, approximately $0.35 \%$ better, and the capital cost reduces by about $2.4 \%$ [17].

To revealing the effect of the solar collector field in the performance of an integrated solar combined cycle system, an exergoeconomic and exergoenvironmental analysis were developed by Cavalcanti. As a result, the net produced and the average cost rate per exergy unit of electricity reach up to $4.2 \%$ and $2.6 \%$, respectively. The average environmental impact per exergy unit of electricity decreased by $3.8 \%$ utilizing solar fields [18]. Vazini and KhoshgoftarManesh performed a 4E dynamic evaluation of a power and water cogeneration plant combined with a solar Parabolic Trough Collector (PTC) and absorption chiller. An accurate thermodynamic simulation of the Qeshm MED-TVC Cogeneration system and improved scenarios were done. Exergetic, Exergoeconomic, and Exergoenvironmental (4E) analyses were performed for base case and retrofit scenarios. Lazhar Achour has interested in the performance of an ISCC plant in the south of Algeria. The authors used a thermodynamic model to assess solar radiation intensity and the total performance of the hybrid solar power plant. The work revealed that solar to electricity efficiency leads to $14.4 \%$ increase over sunny periods and total thermal efficiency of about $60 \%$ is achievable [19]. Amelio evaluated the performance of a novel solar system integrated with a combined cycle plant using oxidant air as heat transfer fluid flowing in linear parabolic collectors. Working at a nominal volumetric flow rate in the daily hours causes $22 \%$ save on fossil fuel and $15.5 \%$ on an annual basis. Furthermore, $60.9 \%$ gain in net average year efficiency and a pay-back of 5 years for the solar field has also been accomplished [20]. By the emergy concept, a thermodynamic, exergo-economic, and exergo-environmental analysis of hybrid geothermalsolar power plant based on the ORC cycle was developed by Alibaba [21]. Ghorbani tried Economic Evaluation of Saline Water Desalination System combined with Flat Plate Solar Collectors in Qeshm Island generating $227.8 \mathrm{kgmole} / \mathrm{h}$ freshwater and $1107 \mathrm{~kW}$ power [22].

Esmaeilzadehazimi has been disclosed a $4 \mathrm{E}$ analysis of integrated magnetohydrodynamic (MHD) combined cycle. The authors have been reported that the cost of exergy destruction decreased, and the efficiency increased in their proposed cycle [23].

Khoshgoftar Manesh evaluated the combined cycle power plant integrated with MSF and MED desalination thermodynamically. The generated power of the integrated systems is decreased by $9.7 \%$ and $8.5 \%$ with the MED and the MSF units, respectively, and the freshwater production in the plant with MED is considerably more than in the plant using MSF [24]. Moradi proposed a hybrid power generation system integrated with a multi-effect desalination unit recovering outlet gases of solid oxide fuel cell for Stirling engine and using outlet gases of Stirling engine as required steam of desalination [25]. Vazini Modaber has developed $4 \mathrm{E}$ analyses to evaluate a MED-TVC and RO desalination unit integrated with power and water cogeneration plant located in Qeshm Island in Iran. The results have modeling 
by Matlab been compared with the simulation in Thermoflex software and the actual data collected from the Qeshm power plant [26].

To improve the design and performance of a combined cycle and steam gas-fired power plant, Khoshgoftar Manesh applied an exergoeconomic and combined pinch and exergy analysis using a computer simulation and analysis program [27].

The performance of a system cannot be estimated efficiently and exactly utilizing energy analysis. consequently, exergy analysis is applied to the accompaniment of energy analysis. Energy balance is not sufficient and conceptual understanding to discover system imperfections, inefficiencies and irreversibilities. Exergy method has become increasingly interested. Exergy assessment as a thermodynamic tool is a powerful measure of energy losses that occur in a system and the costs associated with these inefficiencies and therefore can leads to achieving optimal design. With the aid of exergy analysis environmental impact of energy utilization can be evaluated.

Emergy analysis converts all energies and resources into a single unit of emergy: sej. Despite of energy analysis which does not include environmental energies and human service inputs, in emergy analysis different factors including human economic activities and natural environment evolution can be integrated to compute the contribution of the ecosystem to economic development. Emergy has been widely and continuously used in macroscopic and microscopic fields.

In this study, using a solar parabolic collector to increase the power generation capacity of a real combined cycle power plant in Iran at Qom city has been investigated based on further promising analysis. As shown in the previous studies, there is no study about simultaneous $6 \mathrm{E}$ analysis and evaluation of energy systems or thermal power plants. To have a deep understanding of equipment performance, using simultaneous energy, exergy, exergoeconomic, exergoenvironmental, and emergy-based analysis are a promising way. In this regard, Energy, Exergy, Exergoeconomic, Exergoenvironment, Emergoeconomic, and Emergoenvironment Analysis are performed as $6 \mathrm{E}$ analyses for the base combined cycle and proposed integrated solar combined cycle power plant.

In this study, 6E evaluation of base Qom combined cycle power plant and integrated solar PTC with the existing plant has been investigated to show each system's performance deeply. This analysis indicates different viewpoints of using solar energy.

\section{Case Study}

This power plant consists of two steam units made by ABB Company and four gas units made by MITSUBISHI Company (Model: MW701D), each of which produces 100 MW of steam units and each of the gas units produces 128.5 MW of power. Therefore, the total capacity of the power plant is $714 \mathrm{MW}$. The main fuel of this power plant is natural gas (methane) and it is an alternative fuel to diesel. The exhaust steam from both heat recovery boilers enters the turbine at both HP and IP pressures and enters the condenser after transferring its energy at a lower temperature and pressure under saturated conditions. Due to the limitation and lack of water in the area, the cooling tower of these units is a dry tower or air condenser. Air condensers with large levels of heat transfer and with the help of eighteen fans, distill the steam coming out of the turbine.
The simulation of this plant is performed by Thermoflex software. This plant is including two steam units and four gas units. Likewise, natural gas is considered the main fuel with a lower heating value (LHV) of $46,272 \mathrm{~kJ} / \mathrm{kg}$ and gas oil. The steam from both heat recovery boilers enters the turbine at both HP and IP pressures. After transferring its energy, the undersaturation condition enters the condenser at lower temperatures and pressures. In addition, to enhance the CC efficiency solar thermal power plant is adopted. Solar energy as an opportunity of combining renewable energy with CC is used to gain additional steam to be transferred to the Rankine cycle. Due to the limitations and scarcity of water in the area, the cooling tower of these units is a type of dry tower or air condenser. Air condensers with large heat transfer areas distill outlet stream from the turbine using eighteen fans.

The simulation of this plant is performed by Thermoflex software. This plant is including two steam units and four gas units. Likewise, natural gas is considered the main fuel with a lower heating value (LHV) of $46,272 \mathrm{~kJ} / \mathrm{kg}$ and gas oil. The steam from both heat recovery boilers enters the turbine at both HP and IP pressures. After transferring its energy, the undersaturation condition enters the condenser at lower temperatures and pressures. In addition, to enhance the CC efficiency solar thermal power plant is adopted. Solar energy as an opportunity of combining renewable energy with CC is used to gain additional steam to be transferred to the Rankine cycle. Due to the limitations and scarcity of water in the area, the cooling tower of these units is a type of dry tower or air condenser. Air condensers with large heat transfer areas distill outlet stream from the turbine using eighteen fans.

A schematic of the Qom combined cycle power plant is displayed in Figure 1, and the proposed integrated solar combined cycle layout is shown in Figure 2.

\section{Methodology \\ 3.1 Thermodynamic Modeling}

At each point of the CC and ISCC cycles, thermodynamic properties have been calculated in both Thermoflex and MATLAB. In order to analyze $\mathrm{CC}$, the following assumptions have been taken into account:

1. All processes, in this case, were assumed as steadystate and steady-flow.

2. The air and the gases resulting from combustion were considered ideal gases.

3. The energy variation and the kinetic and potential exergies were assumed negligible.

4. The fuel would be injected into the combustion chamber as natural gas.

5. Tree percent of the fuel LHV would be considered as heat loss from the combustion chamber, and other components would be assumed to be adiabatic.

6. The ambient conditions were assumed as identical to the conditions at the input to the compressor.

7. A pressure drops of 0.03 was considered along the HRSG, and 0.05 pressure drop was considered in the combustion chamber.

For the purpose of simulation of ISCC system in a dynamic model, the below assumptions are considered:

1. Eurotrough ET-150 collector is used

2. Therminol-VP1 is considered as HTF 


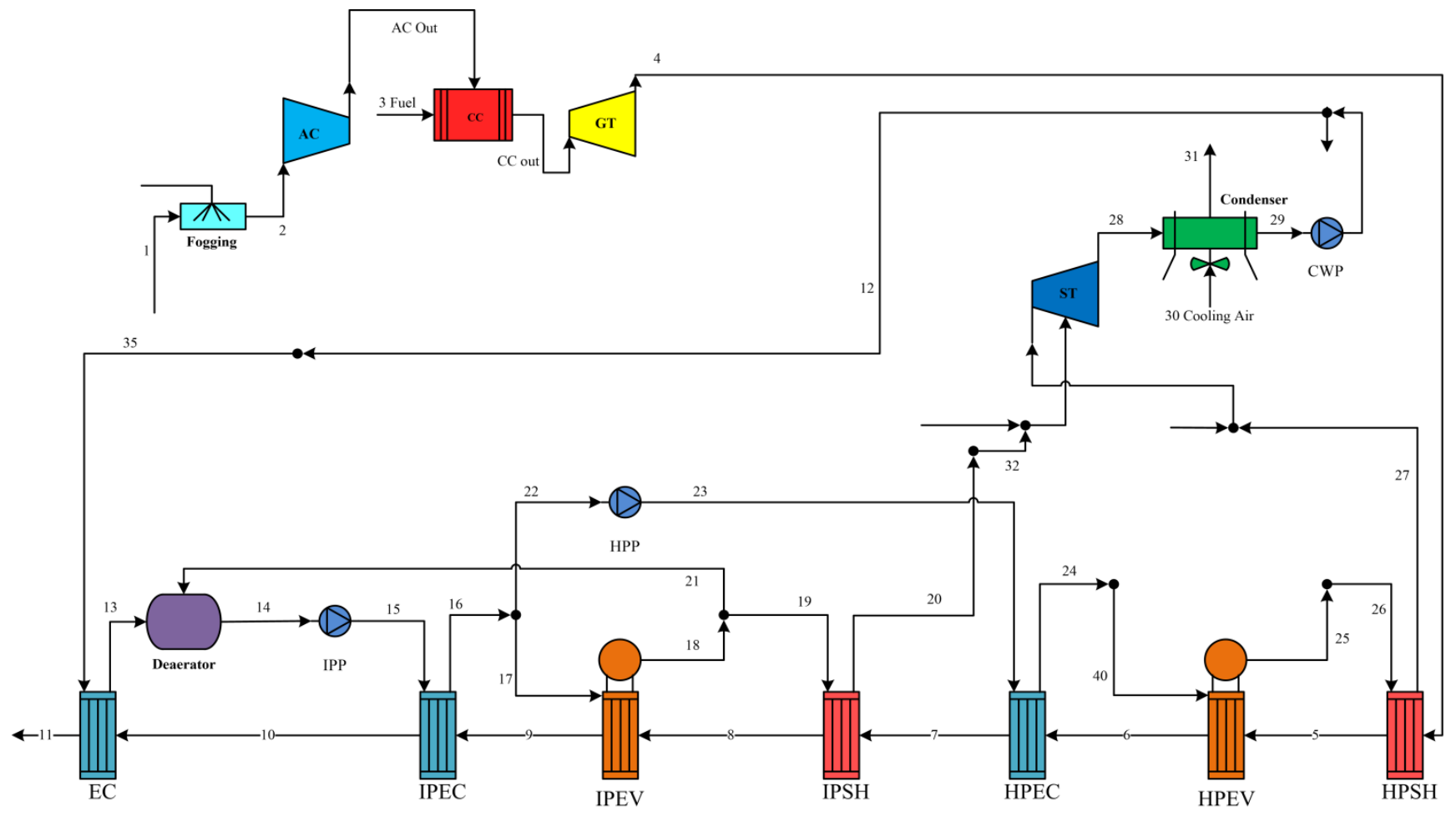

Figure 1. Schematic of Qom combined cycle power plant [21].

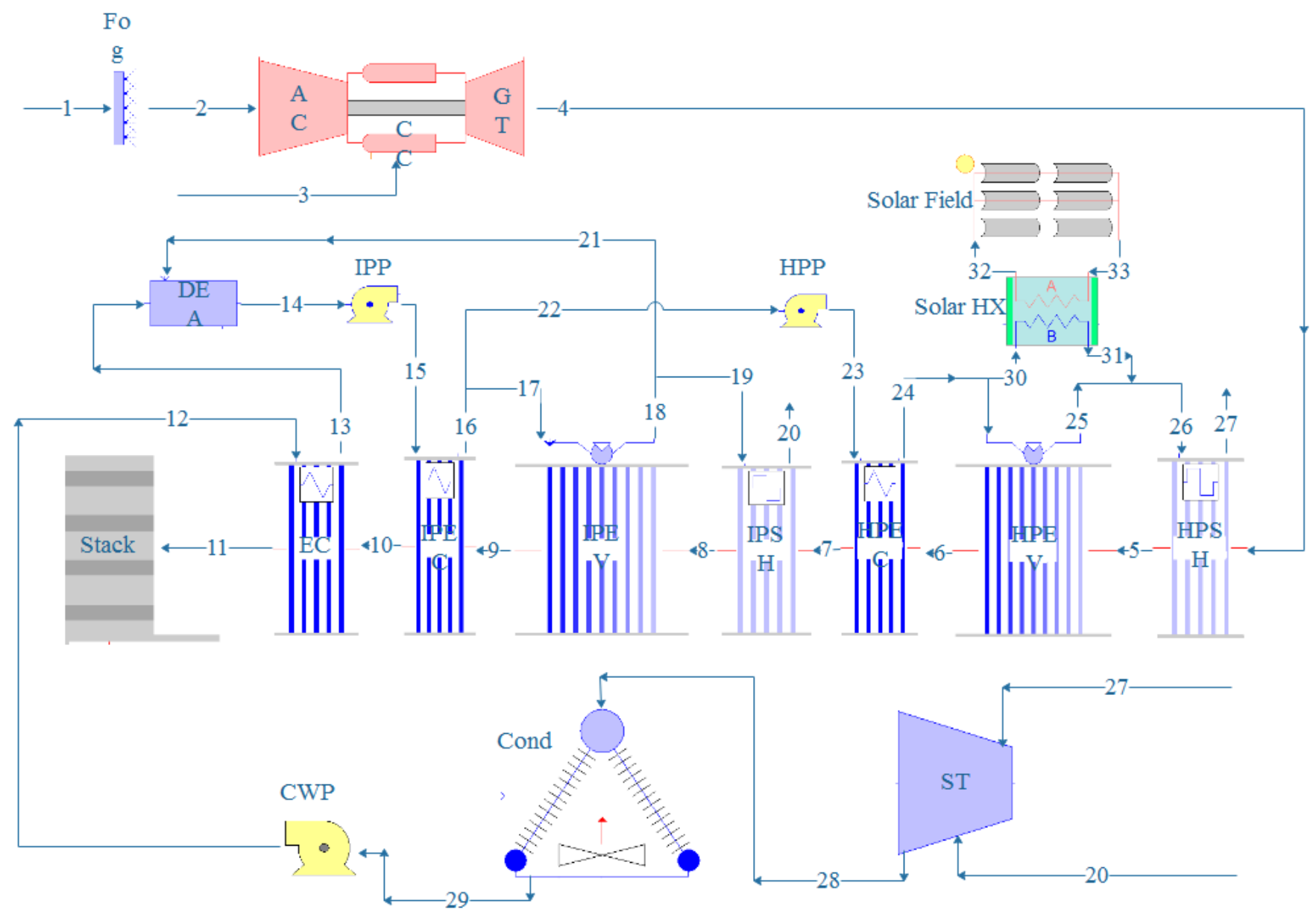

Figure 2. Schematic of retrofit combined cycle power plant. 
3. Solar factor (SF) as a percentage of water mass flow which enters solar field heat exchanger and leads to figuring out the temperature of flow number (6)

4. DNI of seasons is discovered utilizing TRNSYS software

5. The outlet temperature of HPSH is considered 516 ${ }^{\circ} \mathrm{C}$. As a result, other thermodynamic property of point (27) and (26) could be calculated.

6. Pinch temperature and approach temperature are assumed $5^{\circ} \mathrm{C}$ and $4^{\circ} \mathrm{C}$, respectively.

Energy balance for solar field heat exchanger to find out mass flow rate of Therminol $\left(m_{33}\right)$ is written as follows [28]

$m_{33} C_{p \text { (therminoll) }}\left(T_{33}-T_{32}\right)=m_{30}\left(h_{31}-h_{30}\right)$

Where,

$C_{p \text { (therminoll })}=1.498+(0.002414) T+\left(5.9591 \times 10^{-6}\right) T^{2}-$

$\left(2.9879 \times 10^{-8}\right) T^{3}+\left(4.4172 \times 10^{-11}\right) T^{4}$

And

$m_{30}=(1-S F) m_{24}$

The available solar irradiation is determined by multiplying the collector aperture $\left(A_{c}\right)$ by the available solar beam irradiation for PTC as follows [28]

$Q_{\text {solar }}=A_{c} \cdot D N I$

And

$A_{c}=n_{\text {mirror }} \cdot A_{\text {mirror }}$

In which $n_{\text {mirror }}$ and $A_{\text {mirror }}$ are defined as the number of mirrors and the area of every mirror.

The EuroTrough collector consists of 12 collector $^{(1}$ modules, and each module is made up of 28 parabolic mirror panels. In fact, it comprises seven along with the horizontal cross and 4 in a vertical axis, therefore $A_{\text {mirror }}$ the calculation is according to Eq. (6) [29]

$A_{\text {mirror }}=\frac{A_{\text {module }}}{7}$

Where

$A_{\text {module }}=12 \times 5.77\left(\mathrm{~m}^{2}\right)$

The following Equation is utilized to obtain useful energy absorbed by the HTF [28]

$Q_{\mathrm{u}}=m_{31} \cdot C_{p(\text { therminoll })} \cdot\left(T_{\text {out }}-T_{\text {in }}\right)$

The thermal efficiency of the solar collectors is computed as follows [28]

$Q_{\mathrm{u}}=\eta_{\mathrm{c}} \cdot Q_{\text {solar }}$

Below, the thermal efficiency equation for solar collectors is given: $\eta_{\mathrm{c}}=0.75-0.000045 .\left(T_{\mathrm{in}}-T_{\mathrm{amb}}\right)-0.039 .\left(\frac{T_{\mathrm{in}}-T_{\text {amb }}}{D N I}\right)-$

0.0003. DNI. $\left(\frac{T_{\mathrm{in}}-T_{\mathrm{amb}}}{D N I}\right)^{2}$

Where $T_{\text {in }}$ is inlet temperature to collector and $T_{\text {amb }}$ is ambient temperature. Hence outlet temperature of collectors $\left(T_{33}\right)$ can be achieved.

Available solar irradiation is different over a year; therefore, the amount of collector's inlet mass flow rate would be changed. In case of low available solar irradiation, required steam should be generated by means of economizer while in month with high available solar irradiation more collector's inlet mass flow rate should be implemented and required steam mostly would be supplied through the solar field. Accordingly, SF should be modified by a variation in months. In order to simulate the ISCC system in a dynamic mode, a loop in Matlab code is employed to calculate SF for every month.

With a collector area of 55,669 $\mathrm{m}^{2}$, the cost of adapting solar field to the Qom plant is $14,852,000 \$$. To obtaining the amount of $\mathrm{kWh}$ power generated by means of solar field per month, the length of day should be multiplied by days of 12 months of the year, and the difference in power generated by the ISCC compared to $\mathrm{CC}$ then, by adding up all power generated by means of solar field per months and multiplying by 20 years the $\mathrm{kWh}$ power generated by means of solar field per year would be determined.

\subsection{Exergy Analysis}

Exergy analysis is based on the second law of thermodynamics and examines the different processes from an efficiency perspective, and evaluates the exergy destruction within individual plant components. When kinetic and potential energy changes are negligible, the specific exergy of a stream is given by:

$e=h-h_{0}-T_{0}\left(s-s_{0}\right)$

The maximum work that can be obtained as a stream passes from an inlet to an outlet of the system is given by [30]:

$e_{2}-e_{1}=h_{2}-h_{1}-T_{0}\left(s_{2}-s_{1}\right)$

Solar exergy, in fact, fuel exergy, is obtained as follows [31]:

$e_{\text {solar }}=Q_{\text {solar }} \cdot\left(1-\left(\left(\frac{4}{3}\right) \cdot\left(\frac{T_{\text {amb }}}{T_{\text {sun }}}\right)\right) \cdot\left(1-0.28 \cdot \ln f_{\text {dill }}\right)\right)$

Where $f_{\text {dill }}$ is defined as dilution factor and is given by;

$f_{\text {dill }}=1.3 \times 10^{-5}$

\subsection{Exergoeconomic Analysis}

To optimize the system and detects the most waste of energy and cost of units, exergoeconomic analysis can be applied for different flows and plant equipment. Levelized cost is used to calculate the capital cost of the system component. The present worth for particular plant equipment may be given as [32]

$P W_{\mathrm{i}}=C_{\mathrm{i}}-S_{\mathrm{n}} \cdot p w f=C_{\mathrm{i}}-0.15 C_{\mathrm{i}}=0.85 C_{\mathrm{i}}$ 
Where $P W$ is present worth, $C_{\mathrm{i}}$ is initial investment cost (US\$), $p w f$ and $S_{n}$ are defined as present worth factor and salvage value, respectively.

Using the capital recovery factor $C R F(i, n)$, the present worth of equipment converts to an annualized cost [33].

$C R F=\frac{A}{P}=\frac{i_{e f f} \cdot\left(1+i_{e f f}\right)^{n}}{\left(1+i_{e f f}\right)^{n-1}}$

$\dot{C}_{\mathrm{k}}(\$ /$ year $)=C R F \cdot P W_{\mathrm{i}}$
Exergoeconomic balance would be utilized for economic analysis of streams as below,

$\sum \dot{C}_{\text {in }}-\sum \dot{C}_{\text {out }}+\dot{Z}_{\mathrm{k}}=0$

In which $\dot{C}=c \cdot \dot{E x}$

And the exergy destruction rate for a component as a control volume operating at a steady-state can be determined as follows [30]:

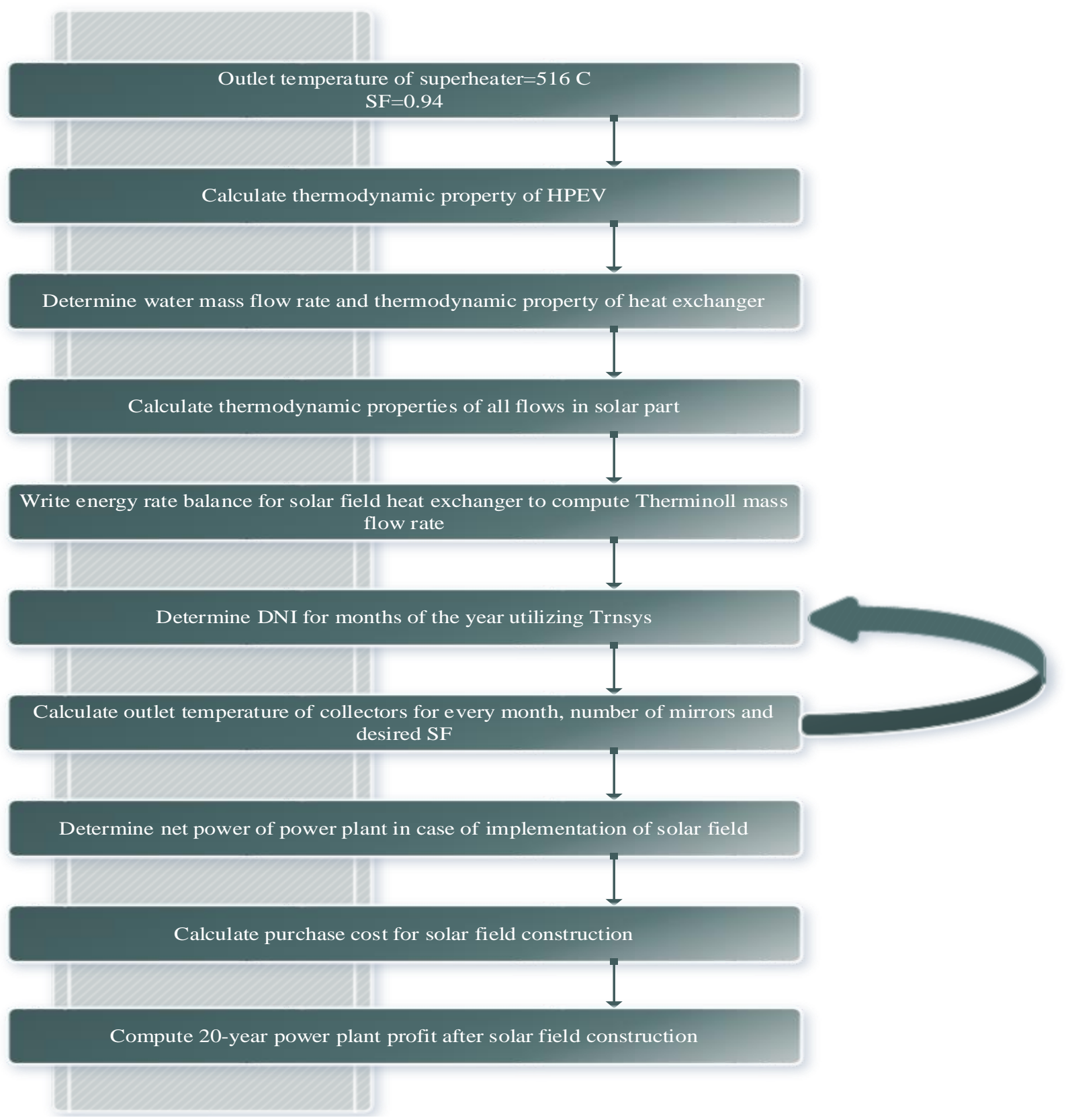

Figure 3. Proposed Computation Algorithm.

By dividing the annualized cost by 8000 annual operating hours, the capital cost for the $k$ th equipment can be calculated [34]:

$\dot{Z}_{\mathrm{k}}=\frac{\Phi_{\mathrm{k}} \cdot \dot{C}_{\mathrm{k}}}{3600 \times 8000}$

The maintenance cost for each component of the plant is defined as $\boldsymbol{\Phi}_{\mathrm{k}}=1.06$. $\sum_{\mathrm{j}} \dot{E}_{\mathrm{qj}} \dot{W}_{\mathrm{cv}}+\sum_{\mathrm{i}} \dot{E}_{\mathrm{i}}-\sum_{\mathrm{e}} \dot{E}_{\mathrm{e}}-\dot{E}_{\mathrm{D}}=0$

Where $\dot{E}_{\mathrm{qj}}$ symbolizes the exergy transfer rate associated with a thermal energy transfer rate and $\dot{W}_{\mathrm{cv}}$ the work rate did. Also, the exergy transfer rates associated with the output and input flow through the control volume are symbolized by $\dot{E}_{e}$ and $\dot{E}_{\mathrm{i}}$, respectively. According to thermodynamic results, the exergetic analysis of all streams is determined. 
Or utilizing product $\left(\dot{E}_{\mathrm{P}, \mathrm{k}}\right)$ and fuel $\left(\dot{E}_{\mathrm{F}, \mathrm{k}}\right)$ definitions and the following exergy rate balance, exergy destruction of the kth component for each component of the system can be computed [30]

$\dot{E}_{\mathrm{F}, \mathrm{k}}=\dot{E}_{\mathrm{P}, \mathrm{k}}+\dot{E}_{\mathrm{D}, \mathrm{k}}$

The exergy efficiency $\left(\varepsilon_{\mathrm{k}}\right)$ for each component of the system can be expressed as follows [30]:

$\varepsilon_{\mathrm{k}}=\frac{\dot{E}_{\mathrm{P}, \mathrm{k}}}{\dot{E}_{F, \mathrm{k}}} \times 100$

The exergy destruction ratio is then determined using the following Equation to figure out their contributions to the overall exergy destruction [30]:

$\mathrm{y}_{\mathrm{D}, \mathrm{k}}=\frac{\dot{E}_{D, k}}{\dot{E}_{D, \text { total }}} \times 100$

\subsection{Exergoenvironmental Analysis}

Many suspended particles, gaseous dioxide, nitrogen oxides, hydrocarbons, carbon dioxide, and carbon monoxide environmental impact studies have been done to reduce the emission from fossil fuels. Therefore, total attention should be paid to protect the environment and reduce unappropriated effects, especially discharging gaseous pollutants, particulates, and wastewater of power plants by optimizing and developing power plants.

By utilizing exergoenvironmental analysis, the environmental impacts of thermodynamic incompetencies would be determined. The purpose is to recognize which equipment has the environmental degradation, to remove these inefficiencies.

The environmental impacts balance equation for each component of power plants is as follow [35]:

$\dot{B}_{\mathrm{P}, \mathrm{k}}=\dot{B}_{\mathrm{F}, \mathrm{k}}+\dot{Y}_{\mathrm{k}}$

$b_{\mathrm{P}, \mathrm{k}} \dot{E}_{\mathrm{P}, \mathrm{k}}=b_{\mathrm{F}, \mathrm{k}} \dot{E}_{\mathrm{F}, \mathrm{k}}+\dot{Y}_{\mathrm{k}}$

In these equations, $\dot{Y}_{\mathrm{k}}$ is the environmental impacts of each component, $\dot{B}_{\mathrm{P}, \mathrm{k}}$ and $\dot{B}_{\mathrm{F}, \mathrm{k}}$ are the environmental impacts of the product and fuel of each component, respectively. $b_{\mathrm{P}, \mathrm{k}}$, and $b_{\mathrm{P}, \mathrm{k}}$ are environmental impacts of product and fuel per unit of exergy.

\section{Emergy analysis}

Emergy is defined as an effective measure of available energy, materials, services, etc., as a function of Solar Equivalent Joule or Solar Emergy Joule (sej), which is, directly and indirectly, used to generate a flow.

For conceptual matching with exergoeconomic and exergoenvironmental analysis, $\beta(\approx 0.93)$ or scale factor is employed to convert energy-based emergency values to an exergy-based emergency. This coefficient as a function of ambient temperature $\left(T_{0}\right)$ and temperature of the $\operatorname{Sun}\left(T_{\mathrm{S}}\right)$ is attained as follows [36].

$\beta=1+\frac{1}{3}\left(\frac{T 0}{T s}\right)^{4}-\frac{4}{3}\left(\frac{T 0}{T s}\right)$

\subsection{Emergy-based exergoeconomic analysis}

To assign emergy or cost-based emergy to exergy flows SPECO method is applied [37]. The monetary emergency rate as a function of the exergy rate and the specific emergoeconomic is expressed as follows [38]:

$\dot{M}_{\mathrm{i}}=m_{\mathrm{i}} \dot{E}_{\mathrm{i}}$

In addition, the monetary emergy rate allocated to heat and work can be determined as follows [38]:

$\dot{M}_{\mathrm{q}}=m_{\mathrm{q}} \dot{E}_{\mathrm{q}}$

$\dot{M}_{\mathrm{w}}=m_{\mathrm{w}} \dot{E}_{\mathrm{w}}$

An emergy-based exergoeconomic balance for each component of the cycle is written as [38]:

$\dot{M}_{\mathrm{P}, \mathrm{k}}=\dot{M}_{\mathrm{F}, \mathrm{k}}+\dot{U}_{\mathrm{k}}$

$m_{\mathrm{P}, \mathrm{k}} \dot{E}_{\mathrm{P}, \mathrm{k}}=m_{\mathrm{F}, \mathrm{k}} \dot{E}_{\mathrm{F}, \mathrm{k}}+\dot{U}_{\mathrm{k}}$

In addition to the monetary emergency rate associated with streams. The component-related emergoeconomic rate $\dot{U}_{k}(\mathrm{sej} / \mathrm{s}$ or $\mathrm{sej} / \mathrm{h})$ for the kth component is expressed as follows [38]:

$\dot{U}_{\mathrm{k}}=\dot{U}_{\mathrm{k}}^{\mathrm{CI}}+\dot{U}_{\mathrm{k}}^{\mathrm{OM}}$

The specific emergoeconomic values for fuel and product of the component $\mathrm{k}$ are calculated [38]:

$m_{\mathrm{P}, \mathrm{k}}=\frac{\dot{M}_{\mathrm{P}, \mathrm{k}}}{\dot{E}_{\mathrm{P}, \mathrm{k}}}$
$m_{\mathrm{F}, \mathrm{k}}=\frac{\dot{M}_{\mathrm{F}, \mathrm{k}}}{\dot{E}_{\mathrm{F}, \mathrm{k}}}$

To compute the emergoeconomic rate associated with the exergy destruction of each component $\left(\dot{M}_{\mathrm{D}, \mathrm{k}}\right)$ Equation (35) is utilized [38]:

$\dot{M}_{\mathrm{D}, \mathrm{k}}=m_{\mathrm{F}, \mathrm{k}} \dot{E}_{\mathrm{D}, \mathrm{k}}$

The total emergoeconomic rate of the kth component $\left(\dot{M}_{\text {тот, } \mathrm{k}}\right)$ is obtained as follows [38]:

$\dot{M}_{\mathrm{TOT}, \mathrm{k}}=\dot{M}_{\mathrm{D}, \mathrm{k}}+\dot{U}_{\mathrm{k}}$

The relative emergoeconomic difference $\left(r_{\mathrm{m}, \mathrm{k}}\right)$ between the average emergoeconomic of the product and the fuel is determined as follows [38]:

$r_{\mathrm{m}, \mathrm{k}}=\frac{m_{\mathrm{P}, \mathrm{k}}-m_{\mathrm{F}, \mathrm{k}}}{m_{\mathrm{F}, \mathrm{k}}} \times 100$

The ratio of component-related emergoeconomic rate to total emergoeconomic rate of each component is defined as the emergy-based exergoeconomic factor $\left(f_{\mathrm{m}, \mathrm{k}}\right)$ which is as follows [38]:

$f_{\mathrm{m}, \mathrm{k}}=\frac{\dot{U}_{\mathrm{k}}}{\dot{U}_{\mathrm{k}}+\dot{M}_{\mathrm{D}, \mathrm{k}}}$

\subsection{Emergy-based exergoenvironmental Analysis}

The ecological emergy rate $\left(\dot{N}_{\mathrm{i}}\right)$ is a product of the emergy rate per unit time, sej/s or $\mathrm{sej} / \mathrm{h}$. By multiplying the exergy rate of the stream $\left(\dot{E}_{\mathrm{i}}\right)$ by the specific 
emergoenvironmental of that stream $\left(n_{\mathrm{i}}\right)$ the emergoenvironmental rate of each flow is calculated [38]:

$\dot{N}_{\mathrm{i}}=n_{\mathrm{i}} \dot{E}_{\mathrm{i}}$

In addition, the emergoenvironmental rate allocated to heat and work can be determined as follows [38]:

$\dot{N}_{\mathrm{q}}=n_{\mathrm{q}} \dot{E}_{\mathrm{q}}$

$\dot{N}_{\mathrm{w}}=n_{\mathrm{w}} \dot{E}_{\mathrm{w}}$

An emergy-based exergoenvironmental balance for the kth component of the cycle is written as [38]:

$\dot{N}_{\mathrm{P}, \mathrm{k}}=\dot{N}_{\mathrm{F}, \mathrm{k}}+\dot{V}_{\mathrm{k}}$

$n_{\mathrm{P}, \mathrm{k}} \dot{E}_{\mathrm{P}, \mathrm{k}}=n_{\mathrm{F}, \mathrm{k}} \dot{E}_{\mathrm{F}, \mathrm{k}}+\dot{V}_{\mathrm{k}}$

In addition to the emergoenvironmental rate associated with streams. The component-related ecological emergy rate $\dot{V}_{\mathrm{k}}$ (sej/s or sej/h) for each component is expressed as follows [38]:

$\dot{V}_{\mathrm{k}}=\dot{V}_{\mathrm{k}}^{\mathrm{CO}}+\dot{V}_{\mathrm{k}}^{\mathrm{OM}}+\dot{V}_{\mathrm{k}}^{\mathrm{DI}}$

The specific emergoenvironmental values for fuel and product of the component $\mathrm{k}$ are calculated [38]:

$n_{\mathrm{P}, \mathrm{k}}=\frac{\dot{N}_{\mathrm{P}, \mathrm{k}}}{\dot{E}_{\mathrm{P}, \mathrm{k}}}$

$n_{\mathrm{F}, \mathrm{k}}=\frac{\dot{N}_{\mathrm{F}, \mathrm{k}}}{\dot{E}_{\mathrm{F}, \mathrm{k}}}$

To compute the emergoenvironmental rate associated with the exergy destruction of each component $\left(\dot{N}_{\mathrm{D}, \mathrm{k}}\right)$ Eq. $(38)$ is utilized [38]:

$\dot{N}_{\mathrm{D}, \mathrm{k}}=n_{\mathrm{F}, \mathrm{k}} \dot{E}_{\mathrm{D}, \mathrm{k}}$

The total emergoenvironmental rate of each component of the system $\left(\dot{N}_{\text {тот,k }}\right)$ is given by [38]:

$\dot{N}_{\mathrm{TOT}, \mathrm{k}}=\dot{N}_{\mathrm{D}, \mathrm{k}}+\dot{V}_{\mathrm{k}}$

The relative ecological emergy difference $\left(r_{\mathrm{m}, \mathrm{k}}\right)$ between the average ecological emergy of the product and the fuel is expressed as Eq. (49) [38].

$r_{\mathrm{m}, \mathrm{k}}=\frac{n_{\mathrm{p}, \mathrm{k}}-n_{\mathrm{F}, \mathrm{k}}}{n_{\mathrm{F}, \mathrm{k}}} \times 100$

The ratio of component-related ecological emergy rate to total ecological emergy rate of each component is defined as the emergy-based exergoenvironmental factor $\left(f_{\mathrm{m}, \mathrm{k}}\right)$ which is as follows [38]:

$f_{\mathrm{m}, \mathrm{k}}=\frac{\dot{V}_{\mathrm{k}}}{\dot{V}_{\mathrm{k}}+\dot{N}_{\mathrm{D}, \mathrm{k}}}$

\section{Results}

\subsection{Thermodynamic Analysis \& Verification}

The thermodynamic simulation has been verified with plant data and Thermoflex Software. Table 1 shows the difference between Thermoflex Software and Matlab code. In addition, Table 2 determines the verification results at the integrated solar PTC with Qom combined cycle. Table 1 and Table 2 show that the thermodynamic simulation in the base case and hybridized case have high accuracy. The power capacity of the integrated system increased by $7.14 \%$ rather than the base plant. This capacity is added to the steam cycle plant. In addition, due to using solar energy, the electrical efficiency of the power plant increased to $47 \%$, showing that the efficiency is raised by $4.44 \%$.

\subsection{Exergy analysis}

Table 3 and Table 4 respectively present the expressions used in the exergoeconomic analysis for both with and without solar field system of each component of the cycle.

The time working of the plant without solar integration, calculations indicated that for the combustion chamber, the related cost of exergy destruction is significantly higher than other components. The highest exergy destruction belongs to the combustion chamber, condenser and steam turbine and pumps, low-pressure superheater, and intermediate pressure economizer own the least exergy destruction.

And from the data of Table. 4, when the ISCC cycle is under consideration, combustion chamber, condenser, steam turbine, gas turbine, and collector have the highest exergy destruction, whereas pumps, intermediate pressure superheater, and intermediate pressure economizer are ranked as the least exergy destruction components. It should be noted that the Solar Field combination improves steam turbine exergy destruction.

Exergy analysis shows the exergy destruction of solar integrated system is increased by $7.2 \%$; However, the power generation of proposed cycle is raised significantly. The exergy destruction per one MW net power is increased by $3.3 \%$.

\subsection{Exergoeconomic Analysis}

Table 5 lists cost rate $\left(\dot{Z}_{\mathrm{k}}\right)$, exergy destruction cost rate $\left(\dot{C}_{\mathrm{D}, \mathrm{k}}\right)$, fuel and product cost per exergy unit $\left(\dot{\mathrm{c}}_{\mathrm{F}, \mathrm{k}}, \dot{\mathcal{C}}_{\mathrm{P}, \mathrm{k}}\right)$, relative cost difference $\left(r_{k}\right)$ and exergoeconomic factor $\left(f_{k}\right)$ for each component.

The time Qom power plant is put forward result Table 5 denotes that the highest cost $\dot{Z}_{\mathrm{k}}+\dot{C}_{\mathrm{D}, \mathrm{k}}$ is associated with the combustion chamber, deaerator, and condenser, and the least belongs to pumps, intermediate pressure superheater, and intermediate pressure economizer. Comparing components with the highest cost, deaerator, condenser, and combustion chamber are ranked as equipment with maximal $r_{\mathrm{k}}$.

In the case of integration of Qom power plant with solar field Table 6 , the highest cost $\dot{Z}_{\mathrm{k}}+\dot{C}_{\mathrm{D}, \mathrm{k}}$ is attributable to pumps, deaerator, and condenser. The least belong to pumps, intermediate pressure superheater, intermediate pressure economizer, steam turbine, and collectors. Comparing components with the highest cost, deaerator, condenser, and combustion chamber are ranked as equipment with maximal $r_{\mathrm{k}}$.

Components associated with the lower value of $f_{\mathrm{k}}$ Suggests enhancement in exergetic efficiency through improvements in its effectiveness. However, it should be noted that this increase will not have a negative effect on the exergy destruction and the efficiency of other equipment.

Results indicate the total $\dot{Z}_{\mathrm{k}}+\dot{C}_{\mathrm{D}, \mathrm{k}}$ is increased by $11.26 \%$ in the integrated solar power plant. Also, the $\dot{Z}_{\mathrm{k}}+$ $\dot{C}_{\mathrm{D}, \mathrm{k}}$ per one MW power generation is raised by $9.07 \%$. 
Table 1. Validation of Thermodynamic Simulation in Base Case.

\begin{tabular}{|c|c|c|c|c|c|c|c|c|c|c|}
\hline \multirow{3}{*}{ Streams } & \multirow{3}{*}{$\begin{array}{c}\text { Material of } \\
\text { stream }\end{array}$} & \multicolumn{3}{|c|}{ Thermoflex simulation } & \multicolumn{3}{|c|}{ Matlab code } & \multicolumn{3}{|c|}{ Variation } \\
\hline & & $\dot{\mathrm{m}}$ & $\mathrm{T}$ & $\mathrm{P}$ & $\dot{\mathrm{m}}$ & $\mathrm{T}$ & $\mathrm{P}$ & $\dot{\mathrm{m}}$ & $\mathrm{T}$ & $\mathrm{P}$ \\
\hline & & {$[\mathrm{kg} / \mathrm{s}]$} & {$[\mathrm{k}]$} & [bar] & {$[\mathrm{kg} / \mathrm{s}]$} & {$[\mathrm{k}]$} & [bar] & {$[\%]$} & [\%] & [\%] \\
\hline 1 & Air & 369.1 & 304.15 & 0.89 & 378.46 & 304.15 & 0.89 & 2.53 & 0 & 0 \\
\hline 2 & Air & 381.3 & 289.81 & 0.85 & 378.46 & 289.81 & 0.85 & 0.74 & 0 & 0 \\
\hline $\mathrm{AC}$ out & Air & 381.3 & 630.21 & 12.37 & 378.46 & 633.68 & 12.36 & 0.74 & 0.55 & 0.08 \\
\hline 3 & $\mathrm{CH} 4$ & 7.58 & 350.77 & 23.02 & 7.55 & 350.77 & 23.02 & 0.39 & 0 & 0 \\
\hline $\mathrm{CC}$ out & Flue Gas & 388.9 & 1372.55 & 11.57 & 386.02 & 1380 & 11.57 & 0.74 & 0.54 & 0 \\
\hline 4 & Flu Gas & 388.9 & 796.05 & 0.93 & 386.02 & 800.42 & 0.93 & 0.74 & 0.54 & 0 \\
\hline 5 & Flu Gas & 388.9 & 735.95 & 0.92 & 386.02 & 738.87 & 0.92 & 0.74 & 0.4 & 0 \\
\hline 6 & Flu Gas & 388.9 & 589.15 & 0.91 & 386.02 & 589.18 & 0.91 & 0.74 & 0.01 & 0 \\
\hline 7 & Flu Gas & 388.9 & 525.55 & 0.91 & 386.02 & 526.98 & 0.91 & 0.74 & 0.27 & 0 \\
\hline 8 & Flu Gas & 388.9 & 524.15 & 0.91 & 386.02 & 525.53 & 0.91 & 0.74 & 0.26 & 0 \\
\hline 9 & Flu Gas & 388.9 & 451.65 & 0.90 & 386.02 & 451.64 & 0.90 & 0.74 & 0.002 & 0 \\
\hline 10 & Flu Gas & 388.9 & 440.35 & 0.90 & 386.02 & 441.25 & 0.90 & 0.74 & 0.20 & 0 \\
\hline 11 & Flu Gas & 388.9 & 402.45 & 0.90 & 386.02 & 404.77 & 0.90 & 0.74 & 0.58 & 0 \\
\hline 12 & Water/steam & 58.36 & 337.93 & 3.6 & 60.52 & 337.49 & 3.70 & 3.70 & 0.13 & 2.78 \\
\hline 13 & Water/steam & 58.36 & 401.95 & 3.6 & 60.52 & 402.25 & 3.70 & 3.70 & 0.07 & 2.78 \\
\hline 14 & Water/steam & 60.26 & 413.05 & 3.6 & 61.48 & 414.04 & 3.70 & 2.02 & 0.24 & 2.78 \\
\hline 15 & Water/steam & 60.26 & 413.15 & 6.12 & 61.48 & 414.07 & 6.12 & 2.02 & 0.22 & 0 \\
\hline 16 & Water/steam & 60.26 & 431.65 & 5.94 & 61.48 & 431.64 & 5.94 & 2.02 & 0.002 & 0 \\
\hline 17 & Water/steam & 15.04 & 431.65 & 5.94 & 15.85 & 431.64 & 5.94 & 5.39 & 0.002 & 0 \\
\hline 18 & Water/steam & 15.04 & 431.65 & 5.94 & 15.85 & 431.64 & 5.94 & 5.39 & 0.002 & 0 \\
\hline 19 & Water/steam & 13.60 & 431.65 & 5.94 & 14.47 & 431.64 & 5.94 & 6.4 & 0.002 & 0 \\
\hline 20 & Water/steam & 13.60 & 450.05 & 5.72 & 14.47 & 450.04 & 5.72 & 6.4 & 0.002 & 0 \\
\hline 21 & Water/steam & 1.29 & 431.65 & 5.94 & 1.26 & 431.64 & 5.94 & 2.32 & 0.002 & 0 \\
\hline 22 & Water/steam & 44.76 & 431.65 & 83.62 & 45.62 & 431.64 & 83.62 & 1.92 & 0.002 & 0 \\
\hline 23 & Water/steam & 44.76 & 433.85 & 81.18 & 45.62 & 432.55 & 83.62 & 1.92 & 0.3 & 3.01 \\
\hline 24 & Water/steam & 44.76 & 564.15 & 81.18 & 45.62 & 562.85 & 81.18 & 1.92 & 0.23 & 0 \\
\hline 25 & Water/steam & 44.76 & 569.15 & 81.18 & 45.62 & 569.18 & 81.18 & 1.92 & 0.01 & 0 \\
\hline 26 & Water/steam & 44.76 & 569.15 & 81.18 & 45.62 & 569.18 & 81.18 & 1.92 & 0.01 & 0 \\
\hline 27 & Water/steam & 44.76 & 756.85 & 78.44 & 45.62 & 483.73 & 78.44 & 1.92 & 36.08 & 0 \\
\hline 28 & Water/steam & 116.7 & 339.62 & 0.26 & 121.05 & 339.59 & 0.26 & 3.73 & 0.01 & 0 \\
\hline 29 & Water/steam & 116.7 & 337.48 & 0.60 & 121.05 & 337.48 & 0.60 & 3.73 & 0 & 0 \\
\hline
\end{tabular}

Table 2. Validation of Thermodynamic Simulation in Hybridized Case.

\begin{tabular}{|c|c|c|c|c|c|c|c|c|c|c|}
\hline \multirow[b]{2}{*}{ Stream } & \multirow[b]{2}{*}{$\begin{array}{c}\text { Material of } \\
\text { stream }\end{array}$} & \multicolumn{3}{|c|}{ Thermoflex simulation } & \multicolumn{3}{|c|}{ Matlab code } & \multicolumn{3}{|c|}{ Variation } \\
\hline & & $\underset{[\mathrm{kg} / \mathrm{s}]}{\dot{\mathrm{m}}}$ & $\begin{array}{c}\mathrm{T} \\
{[\mathrm{k}]}\end{array}$ & $\begin{array}{c}\mathrm{P} \\
{[\mathrm{bar}]}\end{array}$ & $\begin{array}{c}\dot{\mathrm{m}} \\
{[\mathrm{kg} / \mathrm{s}]}\end{array}$ & $\begin{array}{c}\mathrm{T} \\
{[\mathrm{k}]}\end{array}$ & $\begin{array}{c}\mathrm{P} \\
{[\mathrm{bar}]}\end{array}$ & $\dot{\mathrm{m}}$ & $\begin{array}{c}\mathrm{T} \\
{[\%]}\end{array}$ & $\begin{array}{c}\mathrm{P} \\
{[\%]}\end{array}$ \\
\hline 1 & Air & 369.1 & 304.15 & 0.89 & 378.46 & 304.15 & 0.89 & 2.54 & 0 & 0 \\
\hline 2 & Air & 381.3 & 289.81 & 0.85 & 378.46 & 289.81 & 0.85 & 0.74 & 0 & 0 \\
\hline AC out & Air & 381.3 & 630.21 & 12.37 & 378.46 & 633.68 & 12.36 & 0.74 & 0.55 & 0.08 \\
\hline 3 & CH4 & 7.58 & 350.77 & 23.02 & 7.55 & 350.77 & 23.02 & 0.4 & 0 & 0 \\
\hline $\mathrm{CC}$ out & Flue Gas & 388.9 & 1372.55 & 11.57 & 386.02 & 1380 & 11.57 & 0.74 & 0.54 & 0 \\
\hline 4 & Flu Gas & 388.9 & 796.05 & 0.93 & 386.02 & 800.42 & 0.93 & 0.74 & 0.55 & 0 \\
\hline 5 & Flu Gas & 388.9 & 728.05 & 0.92 & 386.02 & 730.75 & 0.92 & 0.74 & 0.37 & 0 \\
\hline 6 & Flu Gas & 388.9 & 589.15 & 0.91 & 386.02 & 590.04 & 0.91 & 0.74 & 0.15 & 0 \\
\hline 7 & Flu Gas & 388.9 & 524.75 & 0.91 & 386.02 & 527.48 & 0.91 & 0.74 & 0.52 & 0 \\
\hline 8 & Flu Gas & 388.9 & 523.25 & 0.91 & 386.02 & 526.39 & 0.91 & 0.74 & 0.6 & 0 \\
\hline 9 & Flu Gas & 388.9 & 450.15 & 0.90 & 386.02 & 452.50 & 0.90 & 0.74 & 0.52 & 0 \\
\hline 10 & Flu Gas & 388.9 & 439.75 & 0.90 & 386.02 & 442.11 & 0.90 & 0.74 & 0.57 & 0 \\
\hline 11 & Flu Gas & 388.9 & 401.75 & 0.90 & 386.02 & 405.63 & 0.90 & 0.74 & 0.97 & 0 \\
\hline 12 & Water/steam & 59.12 & 337.93 & 3.7 & 60.52 & 337.49 & 3.70 & 2.37 & 0.13 & 2.78 \\
\hline 13 & Water/steam & 59.12 & 401.95 & 3.6 & 60.52 & 401.51 & 3.70 & 2.37 & 0.11 & 2.78 \\
\hline 14 & Water/steam & 60.42 & 413.05 & 3.6 & 61.48 & 414.04 & 3.70 & 1.75 & 0.24 & 2.78 \\
\hline 15 & Water/steam & 60.42 & 413.15 & 6.12 & 61.48 & 414.07 & 6.12 & 1.75 & 0.22 & 0 \\
\hline 16 & Water/steam & 60.42 & 430.15 & 5.94 & 61.48 & 431.64 & 5.94 & 1.75 & 0.35 & 0 \\
\hline 17 & Water/steam & 15.13 & 430.15 & 5.94 & 15.85 & 431.64 & 5.94 & 4.76 & 0.35 & 0 \\
\hline 18 & Water/steam & 14.98 & 430.15 & 5.94 & 15.85 & 431.64 & 5.94 & 5.81 & 0.35 & 0 \\
\hline 19 & Water/steam & 13.69 & 430.15 & 5.94 & 14.47 & 431.64 & 5.94 & 5.7 & 0.35 & 0 \\
\hline 20 & Water/steam & 13.69 & 450.05 & 5.72 & 14.47 & 450.04 & 5.72 & 5.7 & 0.002 & 0 \\
\hline 21 & Water/steam & 1.29 & 430.15 & 5.94 & 1.26 & 431.64 & 5.94 & 2.32 & 0.35 & 0 \\
\hline 22 & Water/steam & 45.28 & 430.15 & 83.62 & 45.62 & 431.64 & 83.62 & 0.75 & 0.35 & 0 \\
\hline 23 & Water/steam & 45.28 & 432.35 & 81.18 & 45.62 & 432.55 & 83.62 & 0.75 & 0.05 & 3.01 \\
\hline 24 & Water/steam & 45.28 & 564.15 & 81.18 & 45.62 & 562.85 & 81.18 & 0.75 & 0.23 & 0 \\
\hline 25 & Water/steam & 45.28 & 569.15 & 81.18 & 42,89 & 569.18 & 81.18 & 5.28 & 0.01 & 0 \\
\hline 26 & Water/steam & 45.28 & 569.15 & 81.18 & 45.62 & 569.18 & 81.18 & 0.75 & 0.01 & 0 \\
\hline 27 & Water/steam & 45.28 & 789.15 & 78.44 & 45.62 & 789.15 & 78.44 & 0.75 & 0 & 0 \\
\hline 28 & Water/steam & 117.1 & 339.62 & 0.26 & 121.05 & 339.59 & 0.26 & 3.37 & 0.01 & 0 \\
\hline 29 & Water/steam & 117.1 & 337.48 & 0.60 & 121.05 & 337.48 & 0.60 & 3.37 & 0 & 0 \\
\hline 30 & Water/steam & 10.17 & 564.15 & 81.18 & 10.95 & 562.85 & 81.18 & 7.67 & 0.23 & 0 \\
\hline 31 & Water/steam & 10.17 & 569.15 & 81.18 & 10.95 & 569.18 & 81.18 & 7.67 & 0.01 & 0 \\
\hline 32 & HTF & 1287.3 & 574.15 & 24.31 & 1371.3 & 574.13 & 25 & 6.53 & 0.003 & 2.84 \\
\hline 33 & HTF & 1287.3 & 579.15 & 15.72 & 1371.3 & 579.18 & 16.13 & 6.53 & 0.01 & 2.61 \\
\hline
\end{tabular}


Table 3. Exergy Analysis of Qom Combined Cycle Power Plant.

\begin{tabular}{cccccc}
\hline Component & $\begin{array}{c}\dot{\boldsymbol{E}}_{\boldsymbol{F}, \boldsymbol{k}} \\
{[\mathrm{MW}]}\end{array}$ & $\begin{array}{c}\dot{\boldsymbol{E}}_{\boldsymbol{P}, \boldsymbol{k}} \\
{[\mathrm{MW}]}\end{array}$ & $\begin{array}{c}\dot{\boldsymbol{E}}_{\boldsymbol{D}, \boldsymbol{k}} \\
{[\mathrm{MW}]}\end{array}$ & $\begin{array}{c}\boldsymbol{\varepsilon}_{\boldsymbol{k}} \\
{[\%]}\end{array}$ & $\begin{array}{c}\dot{\boldsymbol{Y}}_{\boldsymbol{k}} \\
{[\%]}\end{array}$ \\
\hline AC & 130.67 & 128.37 & 2.29 & 98.24 & 0.99 \\
CC & 535.90 & 363.56 & 172.34 & 67.84 & 74 \\
GT & 271.81 & 259.73 & 12.08 & 95.56 & 5.21 \\
HPSH & 16.83 & 14.41 & 2.42 & 85.61 & 1.04 \\
HPEV & 36.57 & 31.20 & 5.37 & 85.32 & 2.32 \\
HPEC & 12.85 & 10.80 & 2.05 & 84.04 & 0.88 \\
IPSH & 0.28 & 0.12 & 0.15 & 44.48 & 0.06 \\
IPEV & 12.65 & 9.77 & 2.88 & 77.21 & 1.24 \\
IPEC & 1.54 & 1.30 & 0.23 & 84.57 & 0.1 \\
EC & 4.67 & 2.86 & 1.81 & 61.18 & 0.78 \\
ST & 114.99 & 99.69 & 15.29 & 86.70 & 6.59 \\
IPP & 0.01 & 0.01 & 0.00 & 100 & 0.00 \\
HPP & 0.38 & 0.38 & 0.00 & 100 & 0.00 \\
CWP & 0.41 & 0.41 & 0.44 & 100 & 0.00 \\
Cond & 26.65 & 9.32 & 17.33 & 34.98 & 7.47 \\
DEA & 4.19 & 1.42 & 2.77 & 33.89 & 0.01 \\
\hline
\end{tabular}

Table 4. Exergy Analysis of Hybridized Power Plant.

\begin{tabular}{cccccc}
\hline Component & $\begin{array}{c}\dot{\boldsymbol{E}}_{\boldsymbol{F}, \boldsymbol{k}} \\
{[\mathrm{MW}]}\end{array}$ & $\begin{array}{c}\dot{\boldsymbol{E}}_{\boldsymbol{P}, \boldsymbol{k}} \\
{[\mathrm{MW}]}\end{array}$ & $\begin{array}{c}\dot{\boldsymbol{E}}_{\boldsymbol{D}, \boldsymbol{k}} \\
{[\mathrm{MW}]}\end{array}$ & $\begin{array}{c}\boldsymbol{\varepsilon}_{\boldsymbol{k}} \\
{[\%]}\end{array}$ & $\begin{array}{c}\dot{\boldsymbol{Y}}_{\boldsymbol{k}} \\
{[\%]}\end{array}$ \\
\hline AC & 130.67 & 128.37 & 2.29 & 98.24 & 0.92 \\
CC & 535.90 & 363.56 & 172.34 & 67.84 & 69.19 \\
GT & 271.81 & 259.73 & 12.08 & 95.56 & 4.85 \\
HPSH & 18.96 & 16.61 & 2.34 & 87.62 & 0.94 \\
HPEV & 34.26 & 28.41 & 5.84 & 82.94 & 2.35 \\
HPEC & 12.95 & 10.80 & 2.14 & 83.44 & 0.86 \\
IPSH & 0.21 & 0.12 & 0.08 & 58.79 & 0.03 \\
IPEV & 12.69 & 9.77 & 2.92 & 76.99 & 1.17 \\
IPEC & 1.54 & 1.30 & 0.24 & 84.23 & 0.09 \\
EC & 4.7 & 2.86 & 1.83 & 60.87 & 0.74 \\
ST & 119.4 & 99.69 & 19.70 & 83.49 & 7.91 \\
IPP & 0.01 & 0.01 & 0.00 & 100 & 0.00 \\
HPP & 0.38 & 0.38 & 0.00 & 100 & 0.00 \\
CWP & 0.03 & 0.41 & 0.44 & 100 & 0.00 \\
Cond & 26.65 & 9.32 & 17.33 & 34.98 & 6.96 \\
DEA & 4.19 & 1.42 & 2.77 & 33.89 & 0.01 \\
Solar Field & 19.72 & 9.04 & 10.68 & 45.84 & 4.29 \\
Solar HX & 9.04 & 7.48 & 1.55 & 82.82 & 0.62
\end{tabular}

Table 5. Exergoeconomic Analysis of Base Power Plant.

\begin{tabular}{|c|c|c|c|c|c|c|c|}
\hline Component & $\dot{Z}_{k}[\$ / h]$ & $\dot{C}_{D, k}[\$ / \mathrm{h}]$ & $\dot{Z}_{k}+\dot{C}_{D, k}[\$ / h]$ & $c_{f, k}[\$ / G J]$ & $\boldsymbol{c}_{\boldsymbol{p}, \boldsymbol{k}}[\$ / \mathrm{GJ}]$ & $\boldsymbol{r}_{\boldsymbol{k}}[\%]$ & $\boldsymbol{f}_{\boldsymbol{k}}[\%]$ \\
\hline $\mathrm{AC}$ & 170.53 & 103.43 & 273.96 & 12.50 & 13.09 & 4.74 & 62.24 \\
\hline $\mathrm{CC}$ & 0.83 & 5022 & 5022.83 & 8.09 & 11.93 & 47.41 & 0.01 \\
\hline GT & 11.82 & 518.99 & 530.81 & 11.93 & 12.50 & 4.75 & 2.22 \\
\hline HPSH & 48.86 & 104.06 & 152.92 & 11.93 & 14.88 & 24.70 & 31.95 \\
\hline HPEV & 48.86 & 230.69 & 279.55 & 11.93 & 14.42 & 20.85 & 25.66 \\
\hline HPEC & 48.86 & 88.12 & 136.98 & 11.93 & 15.45 & 29.51 & 35.67 \\
\hline IPSH & 42.48 & 6.74 & 49.22 & 11.93 & 120.72 & 911.64 & 86.30 \\
\hline IPEV & 42.77 & 123.88 & 166.65 & 11.93 & 16.67 & 39.69 & 25.66 \\
\hline IPEC & 52.11 & 10.22 & 62.33 & 11.93 & 25.20 & 111.22 & 83.59 \\
\hline $\mathrm{EC}$ & 51.91 & 77.98 & 129.89 & 11.93 & 24.54 & 105.67 & 39.96 \\
\hline ST & 7.00 & 620.34 & 627.34 & 11.26 & 4.96 & 55.95 & 1.11 \\
\hline IPP & 0.73 & 0.00 & 0.73 & 4.96 & 17.64 & 255.68 & 99.99 \\
\hline HPP & 7.06 & 0.00 & 7.06 & 4.96 & 10.00 & 101.69 & 99.86 \\
\hline CWP & 1.16 & 7.94 & 9.10 & 4.96 & 1.11 & 123.26 & 12.81 \\
\hline Cond & 6.19 & 1421 & 1427.19 & 22.77 & 64.92 & 185.07 & 0.43 \\
\hline DEA & 0.34 & 1512.7 & 1513.04 & 11.93 & 55.85 & 368.14 & 0.02 \\
\hline
\end{tabular}

Table 6. Exergoeconomic Analysis of Hybridized Power Plant.

\begin{tabular}{|c|c|c|c|c|c|c|c|}
\hline Component & $\dot{Z}_{k}[\$ / h]$ & $\dot{C}_{D, k}[\$ / \mathrm{h}]$ & $\dot{Z}_{k}+\dot{C}_{D, k}[\$ / \mathrm{h}]$ & $c_{f, k}[\$ / G J]$ & $c_{p, k}[\$ / G J]$ & $r_{k}[\%]$ & $\boldsymbol{f}_{k}[\%]$ \\
\hline $\mathrm{AC}$ & 170.53 & 103.43 & 273.96 & 12.50 & 13.09 & 4.74 & 62.24 \\
\hline $\mathrm{CC}$ & 0.83 & 5022 & 5022.83 & 8.09 & 11.93 & 47.41 & 0.01 \\
\hline GT & 11.82 & 518.99 & 530.81 & 11.93 & 12.50 & 4.75 & 2.22 \\
\hline HPSH & 48.86 & 100.88 & 149.74 & 11.93 & 14.43 & 20.97 & 32.63 \\
\hline HPEV & 48.86 & 251.01 & 299.87 & 11.93 & 14.85 & 24.51 & 16.13 \\
\hline HPEC & 48.86 & 92.10 & 140.96 & 11.93 & 15.55 & 30.34 & 34.61 \\
\hline IPSH & 42.48 & 3.78 & 46.26 & 11.93 & 128.61 & 977.79 & 92.83 \\
\hline IPEV & 42.77 & 125.46 & 168.23 & 11.93 & 16.71 & 40.07 & 25.42 \\
\hline IPEC & 52.11 & 10.49 & 62.60 & 11.93 & 25.26 & 111.70 & 83.23 \\
\hline EC & 51.91 & 79.01 & 130.92 & 11.93 & 24.64 & 106.50 & 39.65 \\
\hline ST & 7.00 & 793.36 & 800.36 & 11.26 & 5.17 & 53.74 & 0.87 \\
\hline IPP & 0.73 & 0.00 & 0.73 & 5.17 & 17.85 & 245.23 & 99.99 \\
\hline HPP & 7.06 & 0.01 & 7.07 & 5.17 & 10.21 & 97.54 & 99.85 \\
\hline CWP & 1.16 & 8.28 & 9.42 & 5.17 & 1.16 & 122.61 & 12.35 \\
\hline Cond & 6.19 & 1439 & 1445.16 & 22.77 & 65.74 & 185.08 & 0.42 \\
\hline DEA & 0.34 & 1582.6 & 1582.94 & 11.93 & 58.14 & 387.34 & 0.02 \\
\hline Solar Field & 570.42 & 0.00 & 570.42 & 0.00 & 17.52 & - & 100 \\
\hline Solar HX & 187.30 & 130.15 & 317.45 & 23.26 & 28.10 & 20.73 & 59.00 \\
\hline
\end{tabular}

\subsection{Exergoenvironment analysis}

According to the model depicted previously, the exergoenvironmental analysis for the two power plant configurations with and without solar field is estimated. The total environmental impact rate associated with a component $\dot{B}_{\text {тот }}$ is a function of environmental impacts $\dot{Y}_{\mathrm{k}}$ and environmental impact rate associated with the exergy destruction $\dot{B}_{\mathrm{D}, \mathrm{k}}$.

In case of configuration without solar field Table 7, combustion chamber, condenser, and steam turbine have the highest amount of $\dot{B}_{\text {Тот }}$ whereas pumps, intermediate pressure superheater, and intermediate pressure economizer are ranked as the least. When the ISCC cycle Table. 8 is under consideration combustion chamber, condenser, and steam turbine have the highest amount of $\dot{B}_{\text {тот }}$ whereas the least is attributable to pumps, collector, and intermediate pressure superheater.

To improve power plant environmentally, condenser, as a result of the component with the highest $\dot{B}_{\text {тот }}$ and the highest improvement potential $r_{\mathrm{b}, \mathrm{k}}$ is considered. 
Components associated with the lower value of $f_{\mathrm{b}, \mathrm{k}}$ suggests enhancement in exergetic efficiency through improvement in its effectiveness. However, it should be noted that this increase will not have a negative effect on the exergy destruction and the efficiency of other equipment.
As shown, the overall $\dot{Y}_{\mathrm{k}}+\dot{B}_{\mathrm{D}, \mathrm{k}}$ is increased by $1,67 \%$; However, the $\dot{Y}_{\mathrm{k}}+\dot{B}_{\mathrm{D}, \mathrm{k}}$ per MW power generation is reduced by $0.28 \%$.

Table 7. Exergoenvironmental Analysis of the base Power Plant.

\begin{tabular}{|c|c|c|c|c|c|c|c|}
\hline Component & $\dot{\boldsymbol{Y}}_{\boldsymbol{k}}[\mathrm{pts} / \mathrm{s}]$ & $\dot{\boldsymbol{B}}_{\boldsymbol{D}, \boldsymbol{k}}[\mathrm{pts} / \mathrm{s}]$ & $\dot{\boldsymbol{Y}}_{\boldsymbol{k}}+\dot{\boldsymbol{B}}_{\boldsymbol{D}, \boldsymbol{k}}[\mathrm{pts} / \mathrm{s}]$ & $\boldsymbol{b}_{F, \boldsymbol{k}}[\mathrm{pts} / \mathrm{GJ}]$ & $\boldsymbol{b}_{\boldsymbol{P}, \boldsymbol{k}}[\mathrm{pts} / \mathrm{GJ}]$ & $\boldsymbol{r}_{\boldsymbol{b}, \boldsymbol{k}}[-]$ & $\boldsymbol{f}_{\boldsymbol{b}, \boldsymbol{k}}[\%]$ \\
\hline $\mathrm{AC}$ & 331.96 & 23036 & 23367.96 & 10.02 & 10.20 & 1.81 & 1.42 \\
\hline $\mathrm{CC}$ & 1688.10 & 1118100 & 1120276.10 & 6.48 & 9.56 & 47.47 & 0.15 \\
\hline GT & 2647.70 & 115590 & 118273.70 & 9.56 & 10.02 & 4.75 & 2.23 \\
\hline HPSH & 2621.10 & 23177 & 25798.10 & 9.56 & 11.35 & 18.71 & 10.15 \\
\hline HPEV & 185.09 & 51380 & 51565.09 & 9.56 & 11.21 & 17.27 & 0.35 \\
\hline HPEC & 57.44 & 19627 & 19684.44 & 9.56 & 11.38 & 19.03 & 0.29 \\
\hline IPSH & 100.87 & 1501.4 & 1602.27 & 9.56 & 22.31 & 133.22 & 6.29 \\
\hline IPEV & 114.52 & 27592 & 27706.52 & 9.56 & 12.40 & 29.63 & 0.41 \\
\hline IPEC & 10.12 & 2278 & 2288.12 & 9.56 & 11.32 & 18.33 & 0.44 \\
\hline EC & 34.23 & 17369 & 17403.24 & 9.56 & 15.64 & 63.56 & 0.19 \\
\hline ST & 2480.30 & 151890 & 154570.30 & 9.92 & 4.38 & 55.87 & 1.60 \\
\hline IPP & 0.00 & 0.003 & 0.003 & 4.38 & 4.38 & 0.004 & 0.006 \\
\hline HPP & 0.00 & 2.42 & 2.42 & 4.38 & 4.38 & 0.14 & 0.00 \\
\hline CWP & 0.00 & 1948.7 & 1948.7 & 4.38 & 4.8 & 100 & 0.00 \\
\hline Cond & 13.45 & 239960 & 239973.45 & 13.84 & 0.00 & 99.99 & 0.005 \\
\hline DEA & 33.55 & 80823 & 80856.55 & 9.56 & 14.4 & 50.62 & 0.04 \\
\hline
\end{tabular}

Table 8. Exergoenvironmental Analysis of Hybridized Power Plant.

\begin{tabular}{|c|c|c|c|c|c|c|c|}
\hline Component & $\dot{\boldsymbol{Y}}_{\boldsymbol{k}}[\mathrm{pts} / \mathrm{s}]$ & $\dot{\boldsymbol{B}}_{\boldsymbol{D}, \boldsymbol{k}}[\mathrm{pts} / \mathrm{s}]$ & $\dot{\boldsymbol{Y}}_{\boldsymbol{k}}+\dot{\boldsymbol{B}}_{\boldsymbol{D}, \boldsymbol{k}}[\mathrm{pts} / \mathrm{s}]$ & $\boldsymbol{b}_{F, \boldsymbol{k}}[\mathrm{pts} / \mathrm{GJ}]$ & $\boldsymbol{b}_{P, \boldsymbol{k}}[\mathrm{pts} / \mathrm{GJ}]$ & $\boldsymbol{r}_{\boldsymbol{b}, \boldsymbol{k}}[-]$ & $\boldsymbol{f}_{\boldsymbol{b}, \boldsymbol{k}}[\%]$ \\
\hline $\mathrm{AC}$ & 331.96 & 23036 & 23367.96 & 10.02 & 10.20 & 1.81 & 1.42 \\
\hline $\mathrm{CC}$ & 1688.10 & 1118100 & 1120276.10 & 6.48 & 9.56 & 47.47 & 0.15 \\
\hline GT & 2647.70 & 115590 & 118273.70 & 9.56 & 10.02 & 4.75 & 2.23 \\
\hline HPSH & 2919.40 & 22469 & 25388.40 & 9.56 & 11.09 & 15.97 & 11.49 \\
\hline HPEV & 177.47 & 55905 & 56082.47 & 9.56 & 11.54 & 20.62 & 0.31 \\
\hline HPEC & 57.44 & 20513 & 20570.44 & 9.56 & 11.47 & 19.89 & 0.27 \\
\hline IPSH & 100.87 & 843.17 & 944.04 & 9.56 & 17.07 & 78.49 & 10.68 \\
\hline IPEV & 114.52 & 27944 & 28058.52 & 9.56 & 12.43 & 30.00 & 0.40 \\
\hline IPEC & 10.12 & 2337 & 2347.12 & 9.56 & 11.36 & 18.81 & 0.43 \\
\hline EC & 34.23 & 17597 & 17631.23 & 9.56 & 15.72 & 64.39 & 0.19 \\
\hline ST & 2480.30 & 199530 & 202010.20 & 10.12 & 4.69 & 53.67 & 1.22 \\
\hline IPP & 0.00 & 0.003 & 0.003 & 4.69 & 4.69 & 0.004 & 0.006 \\
\hline HPP & 0.00 & 2.59 & 2.59 & 4.69 & 4.69 & 0.14 & 0.00 \\
\hline CWP & 0.00 & 2086.5 & 2086.5 & 4.69 & 0.00 & 100 & 0.00 \\
\hline Cond & 13.45 & 236970 & 236983.45 & 13.67 & 0.00 & 99.99 & 0.005 \\
\hline DEA & 33.55 & 60360 & 60393.55 & 9.56 & 12.02 & 25.73 & 0.05 \\
\hline Solar Field & 650.61 & 0.00 & 650.61 & 0.00 & 0.07 & - & 100 \\
\hline Solar HX & 1640.70 & 111.75 & 1752.45 & 0.07 & 0.30 & 325.21 & 93.62 \\
\hline
\end{tabular}

\subsection{Emergy analysis}

\subsubsection{Emergoeconomic}

The highest ecological emergy rate is attributable to the combustion chamber, deaerator, and condenser for both Qom power plant configuration Table 9 and solar field combination Table 10. So, the designer should be more attention to improve these components. The results indicate the $\dot{U}_{\mathrm{k}}+\dot{M}_{\mathrm{D}, \mathrm{k}}$ is increased by $15.4 \%$ and the $\dot{U}_{\mathrm{k}}+\dot{M}_{\mathrm{D}, \mathrm{k}}$ per one MW power generation is raised by $13.04 \%$.

Table 9. Emergoeconomic Analysis of the based Power Plant.

\begin{tabular}{|c|c|c|c|c|c|c|c|}
\hline Component & $\dot{\boldsymbol{U}}_{\boldsymbol{k}}[\mathrm{sej} / \mathrm{h}]$ & $\dot{\boldsymbol{M}}_{\boldsymbol{D}, \boldsymbol{k}}[\mathrm{sej} / \mathrm{h}]$ & $\dot{\boldsymbol{U}}_{\boldsymbol{k}}+\dot{\boldsymbol{M}}_{\boldsymbol{D}, \boldsymbol{k}}[\mathrm{sej} / \mathrm{h}]$ & $\boldsymbol{m}_{\boldsymbol{f}, \boldsymbol{k}}[\mathrm{sej} / \mathrm{kJ}]$ & $\boldsymbol{m}_{\boldsymbol{p}, \boldsymbol{k}}[\mathrm{sej} / \mathrm{kJ}]$ & $\boldsymbol{r}_{\boldsymbol{m}, \boldsymbol{k}}[\%]$ & $\boldsymbol{f}_{\boldsymbol{m}, \boldsymbol{k}}[\%]$ \\
\hline $\mathrm{AC}$ & $1.69 \times 10^{14}$ & $7.29 \times 10^{13}$ & $2.42 \times 10^{14}$ & $8.82 \times 10^{6}$ & $9.34 \times 10^{6}$ & 5.95 & 69.9 \\
\hline $\mathrm{CC}$ & $8.32 \times 10^{11}$ & $3.54 \times 10^{15}$ & $3.54 \times 10^{15}$ & $5.70 \times 10^{6}$ & $8.41 \times 10^{6}$ & 47.41 & 0.02 \\
\hline GT & $1.17 \times 10^{13}$ & $3.66 \times 10^{14}$ & $3.77 \times 10^{14}$ & $8.41 \times 10^{6}$ & $8.82 \times 10^{6}$ & 4.80 & 3.11 \\
\hline HPSH & $4.86 \times 10^{13}$ & $7.34 \times 10^{13}$ & $1.22 \times 10^{14}$ & $8.41 \times 10^{6}$ & $1.07 \times 10^{7}$ & 27.94 & 39.8 \\
\hline HPEV & $4.86 \times 10^{13}$ & $1.62 \times 10^{14}$ & $2.1 \times 10^{14}$ & $8.41 \times 10^{6}$ & $1.03 \times 10^{7}$ & 22.35 & 23.0 \\
\hline HPEC & $4.86 \times 10^{13}$ & $6.21 \times 10^{13}$ & $1.1 \times 10^{14}$ & $8.41 \times 10^{6}$ & $1.12 \times 10^{7}$ & 33.83 & 43.8 \\
\hline IPSH & $4.22 \times 10^{13}$ & $4.75 \times 10^{12}$ & $4.69 \times 10^{13}$ & $8.41 \times 10^{6}$ & $1.12 \times 10^{8}$ & 1234 & 89.8 \\
\hline IPEV & $4.25 \times 10^{13}$ & $8.73 \times 10^{13}$ & $1.3 \times 10^{14}$ & $8.41 \times 10^{6}$ & $1.21 \times 10^{7}$ & 43.88 & 32.7 \\
\hline IPEC & $5.18 \times 10^{13}$ & $7.21 \times 10^{12}$ & $5.9 \times 10^{13}$ & $8.41 \times 10^{6}$ & $2.1 \times 10^{7}$ & 149.4 & 87.7 \\
\hline $\mathrm{EC}$ & $5.16 \times 10^{13}$ & $5.50 \times 10^{13}$ & $1.06 \times 10^{14}$ & $8.41 \times 10^{6}$ & $1.87 \times 10^{7}$ & 123 & 48.4 \\
\hline ST & $6.97 \times 10^{12}$ & $4.21 \times 10^{14}$ & $4.28 \times 10^{14}$ & $7.65 \times 10^{6}$ & $3.37 \times 10^{6}$ & 55.87 & 1.62 \\
\hline IPP & $7.30 \times 10^{11}$ & $8.54 \times 10^{6}$ & $7.30 \times 10^{11}$ & $3.37 \times 10^{6}$ & $1.6 \times 10^{7}$ & 373.8 & 99.9 \\
\hline HPP & $7.02 \times 10^{12}$ & $6.72 \times 10^{9}$ & $7.02 \times 10^{12}$ & $3.37 \times 10^{6}$ & $8.4 \times 10^{6}$ & 148.6 & 99.9 \\
\hline CWP & $1.16 \times 10^{12}$ & $5.40 \times 10^{12}$ & $6.56 \times 10^{12}$ & $3.37 \times 10^{6}$ & $1.03 \times 10^{6}$ & 130.5 & 17.6 \\
\hline Cond & $6.16 \times 10^{12}$ & $1.16 \times 10^{15}$ & $1.16 \times 10^{15}$ & $1.87 \times 10^{7}$ & $5.33 \times 10^{7}$ & 184.9 & 0.52 \\
\hline DEA & $1.01 \times 10^{14}$ & $1.59 \times 10^{15}$ & $1.69 \times 10^{15}$ & $5.28 \times 10^{7}$ & $5.01 \times 10^{7}$ & 5.08 & 119 \\
\hline
\end{tabular}


Table 10. Emergoeconomic Analysis of the Hybridized Power Plant.

\begin{tabular}{|c|c|c|c|c|c|c|c|}
\hline Component & $\dot{\boldsymbol{U}}_{\boldsymbol{k}}[\mathrm{sej} / \mathrm{h}]$ & $\dot{\boldsymbol{M}}_{\boldsymbol{D}, \boldsymbol{k}}[\mathrm{sej} / \mathrm{h}]$ & $\dot{\boldsymbol{U}}_{\boldsymbol{k}}+\dot{\boldsymbol{M}}_{\boldsymbol{D}, \boldsymbol{k}}[\mathrm{sej} / \mathrm{h}]$ & $\boldsymbol{m}_{f, \boldsymbol{k}}[\mathrm{sej} / \mathrm{kJ}]$ & $\boldsymbol{m}_{p, \boldsymbol{k}}[\mathrm{sej} / \mathrm{kJ}]$ & $\boldsymbol{r}_{\boldsymbol{m}, k}[\%]$ & $\boldsymbol{f}_{m, k}[\%]$ \\
\hline $\mathrm{AC}$ & $1.69 \times 10^{14}$ & $7.29 \times 10^{13}$ & $2.42 \times 10^{14}$ & $8.82 \times 10^{6}$ & $9.34 \times 10^{6}$ & 5.95 & 69.9 \\
\hline $\mathrm{CC}$ & $8.32 \times 10^{11}$ & $3.54 \times 10^{15}$ & $3.54 \times 10^{15}$ & $5.70 \times 10^{6}$ & $8.41 \times 10^{6}$ & 47.41 & 0.02 \\
\hline GT & $1.17 \times 10^{13}$ & $3.66 \times 10^{14}$ & $3.77 \times 10^{14}$ & $8.41 \times 10^{6}$ & $8.82 \times 10^{6}$ & 4.80 & 3.11 \\
\hline HPSH & $4.86 \times 10^{13}$ & $7.11 \times 10^{13}$ & $1.19 \times 10^{14}$ & $8.41 \times 10^{6}$ & $1.04 \times 10^{7}$ & 23.78 & 40.5 \\
\hline HPEV & $4.80 \times 10^{13}$ & $1.77 \times 10^{14}$ & $2.25 \times 10^{14}$ & $8.41 \times 10^{6}$ & $1.06 \times 10^{7}$ & 26.14 & 21.3 \\
\hline HPEC & $4.85 \times 10^{13}$ & $6.49 \times 10^{13}$ & $1.13 \times 10^{14}$ & $8.41 \times 10^{6}$ & $1.13 \times 10^{7}$ & 34.65 & 42.7 \\
\hline IPSH & $4.87 \times 10^{13}$ & $2.67 \times 10^{12}$ & $5.13 \times 10^{13}$ & $8.41 \times 10^{6}$ & $1.12 \times 10^{8}$ & 1350 & 94.8 \\
\hline IPEV & $4.25 \times 10^{13}$ & $8.85 \times 10^{13}$ & $1.31 \times 10^{14}$ & $8.41 \times 10^{6}$ & $1.21 \times 10^{7}$ & 44.25 & 32.4 \\
\hline IPEC & $5.18 \times 10^{13}$ & $7.40 \times 10^{12}$ & $5.92 \times 10^{13}$ & $8.41 \times 10^{6}$ & $2.1 \times 10^{7}$ & 149.8 & 87.5 \\
\hline $\mathrm{EC}$ & $5.16 \times 10^{13}$ & $5.57 \times 10^{13}$ & $1.07 \times 10^{14}$ & $8.41 \times 10^{6}$ & $1.88 \times 10^{7}$ & 123.8 & 48.1 \\
\hline ST & $6.97 \times 10^{12}$ & $5.32 \times 10^{14}$ & $5.38 \times 10^{14}$ & $7.50 \times 10^{6}$ & $3.47 \times 10^{6}$ & 53.65 & 1.29 \\
\hline IPP & $7.30 \times 10^{11}$ & $8.80 \times 10^{6}$ & $7.30 \times 10^{11}$ & $3.47 \times 10^{6}$ & $1.6 \times 10^{7}$ & 363 & 99.9 \\
\hline HPP & $7.02 \times 10^{12}$ & $6.92 \times 10^{9}$ & $7.02 \times 10^{12}$ & $3.47 \times 10^{6}$ & $8.49 \times 10^{6}$ & 144.3 & 99.9 \\
\hline CWP & $1.16 \times 10^{12}$ & $5.56 \times 10^{12}$ & $6.72 \times 10^{12}$ & $3.47 \times 10^{6}$ & $1.03 \times 10^{6}$ & 129.8 & 17.2 \\
\hline Cond & $6.16 \times 10^{12}$ & $1.18 \times 10^{15}$ & $1.18 \times 10^{15}$ & $1.90 \times 10^{7}$ & $5.43 \times 10^{7}$ & 184.9 & 0.5 \\
\hline DEA & $1.01 \times 10^{14}$ & $1.68 \times 10^{15}$ & $1.96 \times 10^{15}$ & $1.68 \times 10^{8}$ & $5.32 \times 10^{7}$ & 68.45 & 5.69 \\
\hline Solar Field & $5.67 \times 10^{14}$ & 0 & $5.67 \times 10^{14}$ & 0 & $1.74 \times 10^{7}$ & - & 100 \\
\hline Solar HX & $1.86 \times 10^{14}$ & $9.74 \times 10^{13}$ & $2.83 \times 10^{14}$ & $1.74 \times 10^{7}$ & $2.79 \times 10^{7}$ & 60.38 & 65.6 \\
\hline
\end{tabular}

\subsubsection{Emergoenvironment}

As shown in Table 11, the highest emergy related to environmental impacts is associated with the combustion chamber, condenser, and steam turbine for the two power plant configurations. Compared to other components, the salient point is that the solar field's emergoenvironmental rate is acceptable when solar field integration came under scrutiny, as indicated in Table 12. Results show the overall $\dot{V}_{\mathrm{k}}+\dot{N}_{\mathrm{D}, \mathrm{k}}$ of the solar integrated power plant is increased by $6.2 \%$ rather than base power plant.

Table 11. Emergoenvironmental Analysis of the based Power Plant.

\begin{tabular}{|c|c|c|c|c|c|c|c|}
\hline Component & $\dot{\boldsymbol{V}}_{\boldsymbol{k}}[\mathrm{sej} / \mathrm{h}]$ & $\dot{N}_{D, k}[\mathrm{sej} / \mathrm{h}]$ & $\dot{V}_{k}+\dot{N}_{D, k}[\mathrm{sej} / \mathrm{h}]$ & $\boldsymbol{n}_{\boldsymbol{f}, \boldsymbol{k}}[\mathrm{sej} / \mathrm{kJ}]$ & $\boldsymbol{n}_{\boldsymbol{p}, \boldsymbol{k}}[\mathrm{sej} / \mathrm{kJ}]$ & $\boldsymbol{r}_{\boldsymbol{n}, \boldsymbol{k}}[\%]$ & $\boldsymbol{f}_{n, k}[\%]$ \\
\hline $\mathrm{AC}$ & $5.03 \times 10^{12}$ & $6.32 \times 10^{14}$ & $6.37 \times 10^{14}$ & $7.64 \times 10^{7}$ & $7.78 \times 10^{7}$ & 1.80 & 0.78 \\
\hline $\mathrm{CC}$ & $2.35 \times 10^{13}$ & $3.07 \times 10^{16}$ & $3.07 \times 10^{16}$ & $4.95 \times 10^{7}$ & $7.30 \times 10^{7}$ & 47.44 & 0.07 \\
\hline GT & $3.72 \times 10^{13}$ & $3.17 \times 10^{15}$ & $3.20 \times 10^{15}$ & $7.30 \times 10^{7}$ & $7.64 \times 10^{7}$ & 4.70 & 1.15 \\
\hline HPSH & $3.68 \times 10^{13}$ & $6.37 \times 10^{14}$ & $6.73 \times 10^{14}$ & $7.30 \times 10^{7}$ & $8.60 \times 10^{7}$ & 17.78 & 5.46 \\
\hline HPEV & $6.16 \times 10^{12}$ & $1.41 \times 10^{15}$ & $1.41 \times 10^{15}$ & $7.30 \times 10^{7}$ & $8.56 \times 10^{7}$ & 17.28 & 0.43 \\
\hline HPEC & $1.91 \times 10^{12}$ & $5.39 \times 10^{14}$ & $5.40 \times 10^{14}$ & $7.30 \times 10^{7}$ & $8.69 \times 10^{7}$ & 19.05 & 0.45 \\
\hline IPSH & $1.41 \times 10^{12}$ & $4.12 \times 10^{13}$ & $4.26 \times 10^{13}$ & $7.30 \times 10^{7}$ & $1.67 \times 10^{8}$ & 129.1 & 3.32 \\
\hline IPEV & $3.81 \times 10^{12}$ & $7.58 \times 10^{14}$ & $7.61 \times 10^{14}$ & $7.30 \times 10^{7}$ & $9.47 \times 10^{7}$ & 29.65 & 0.5 \\
\hline IPEC & $3.37 \times 10^{11}$ & $6.26 \times 10^{13}$ & $6.29 \times 10^{13}$ & $7.30 \times 10^{7}$ & $8.64 \times 10^{7}$ & 18.34 & 0.53 \\
\hline $\mathrm{EC}$ & $1.14 \times 10^{12}$ & $4.77 \times 10^{14}$ & $4.78 \times 10^{14}$ & $7.30 \times 10^{7}$ & $1.19 \times 10^{8}$ & 63.59 & 0.23 \\
\hline $\mathrm{ST}$ & $3.48 \times 10^{13}$ & $4.15 \times 10^{15}$ & $4.18 \times 10^{15}$ & $7.55 \times 10^{7}$ & $3.32 \times 10^{7}$ & 55.99 & 0.83 \\
\hline IPP & $1.94 \times 10^{10}$ & $8.41 \times 10^{7}$ & $1.94 \times 10^{10}$ & $3.32 \times 10^{7}$ & $3.35 \times 10^{7}$ & 1.01 & 99.5 \\
\hline HPP & $1.94 \times 10^{10}$ & $6.61 \times 10^{10}$ & $8.55 \times 10^{10}$ & $3.32 \times 10^{7}$ & $3.32 \times 10^{7}$ & 0.18 & 22.7 \\
\hline CWP & $1.94 \times 10^{10}$ & $5.32 \times 10^{13}$ & $5.32 \times 10^{13}$ & $3.32 \times 10^{7}$ & $2.49 \times 10^{6}$ & 107.5 & 0.03 \\
\hline Cond & $4.48 \times 10^{11}$ & $6.60 \times 10^{15}$ & $6.60 \times 10^{15}$ & $1.05 \times 10^{8}$ & $3.02 \times 10^{8}$ & 185.8 & 0.01 \\
\hline DEA & $1.11 \times 10^{12}$ & $2.40 \times 10^{13}$ & $2.51 \times 10^{13}$ & $7.69 \times 10^{7}$ & $1.13 \times 10^{8}$ & 46.94 & 4.87 \\
\hline
\end{tabular}

Table 12. Emergoenvironmental Analysis of the Hybridized Power Plant.

\begin{tabular}{|c|c|c|c|c|c|c|c|}
\hline Component & $\dot{\boldsymbol{V}}_{\boldsymbol{k}}[\mathrm{sej} / \mathrm{h}]$ & $\dot{\boldsymbol{N}}_{D, \boldsymbol{k}}[\mathrm{sej} / \mathrm{h}]$ & $\dot{\boldsymbol{V}}_{\boldsymbol{k}}+\dot{\boldsymbol{N}}_{\boldsymbol{D}, \boldsymbol{k}}[\mathrm{sej} / \mathrm{h}]$ & $\boldsymbol{n}_{f, \boldsymbol{k}}[\mathrm{sej} / \mathrm{kJ}]$ & $\boldsymbol{n}_{\boldsymbol{p}, \boldsymbol{k}}[\mathrm{sej} / \mathrm{kJ}]$ & $\boldsymbol{r}_{n, k}[\%]$ & $\boldsymbol{f}_{n, k}[\%]$ \\
\hline $\mathrm{AC}$ & $5.03 \times 10^{12}$ & $6.32 \times 10^{14}$ & $6.37 \times 10^{14}$ & $7.64 \times 10^{7}$ & $7.78 \times 10^{7}$ & 1.80 & 0.78 \\
\hline $\mathrm{CC}$ & $2.35 \times 10^{13}$ & $3.07 \times 10^{16}$ & $3.07 \times 10^{16}$ & $4.95 \times 10^{7}$ & $7.30 \times 10^{7}$ & 47.44 & 0.07 \\
\hline GT & $3.72 \times 10^{13}$ & $3.17 \times 10^{15}$ & $3.20 \times 10^{15}$ & $7.30 \times 10^{7}$ & $7.64 \times 10^{7}$ & 4.70 & 1.15 \\
\hline HPSH & $4.10 \times 10^{13}$ & $6.17 \times 10^{14}$ & $6.58 \times 10^{14}$ & $7.30 \times 10^{7}$ & $8.40 \times 10^{7}$ & 15.07 & 6.22 \\
\hline HPEV & $5.91 \times 10^{12}$ & $1.53 \times 10^{15}$ & $1.53 \times 10^{15}$ & $7.30 \times 10^{7}$ & $8.81 \times 10^{7}$ & 20.64 & 0.38 \\
\hline HPEC & $1.91 \times 10^{12}$ & $5.63 \times 10^{14}$ & $5.64 \times 10^{14}$ & $7.30 \times 10^{7}$ & $8.75 \times 10^{7}$ & 19.90 & 0.33 \\
\hline IPSH & $1.41 \times 10^{12}$ & $2.31 \times 10^{13}$ & $2.45 \times 10^{13}$ & $7.30 \times 10^{7}$ & $1.27 \times 10^{8}$ & 74.39 & 5.76 \\
\hline IPEV & $3.81 \times 10^{12}$ & $7.68 \times 10^{14}$ & $7.71 \times 10^{14}$ & $7.30 \times 10^{7}$ & $9.49 \times 10^{7}$ & 30.03 & 0.49 \\
\hline IPEC & $3.37 \times 10^{11}$ & $6.42 \times 10^{13}$ & $6.45 \times 10^{13}$ & $7.30 \times 10^{7}$ & $8.68 \times 10^{7}$ & 18.82 & 0.52 \\
\hline $\mathrm{EC}$ & $1.14 \times 10^{12}$ & $4.83 \times 10^{14}$ & $4.84 \times 10^{14}$ & $7.30 \times 10^{7}$ & $1.20 \times 10^{8}$ & 64.42 & 0.23 \\
\hline ST & $3.48 \times 10^{13}$ & $5.46 \times 10^{15}$ & $5.49 \times 10^{15}$ & $7.69 \times 10^{7}$ & $3.55 \times 10^{7}$ & 53.79 & 0.63 \\
\hline IPP & $1.94 \times 10^{10}$ & $9.00 \times 10^{7}$ & $1.94 \times 10^{10}$ & $3.55 \times 10^{7}$ & $3.59 \times 10^{7}$ & 0.94 & 99.5 \\
\hline HPP & $1.94 \times 10^{10}$ & $7.08 \times 10^{10}$ & $9.02 \times 10^{10}$ & $3.55 \times 10^{7}$ & $3.56 \times 10^{7}$ & 0.18 & 21.5 \\
\hline CWP & $1.94 \times 10^{10}$ & $5.69 \times 10^{13}$ & $5.69 \times 10^{13}$ & $3.55 \times 10^{7}$ & $2.66 \times 10^{6}$ & 107.5 & 0.03 \\
\hline Cond & $4.48 \times 10^{11}$ & $6.52 \times 10^{15}$ & $6.52 \times 10^{15}$ & $1.04 \times 10^{8}$ & $2.99 \times 10^{8}$ & 185.8 & 0.01 \\
\hline DEA & $1.11 \times 10^{12}$ & $1.76 \times 10^{15}$ & $1.76 \times 10^{15}$ & $1.76 \times 10^{8}$ & $9.52 \times 10^{7}$ & 46.10 & 0.06 \\
\hline Solar Field & $2.66 \times 10^{13}$ & 0 & $2.66 \times 10^{13}$ & 0 & $8.19 \times 10^{5}$ & - & 100 \\
\hline Solar HX & $2.39 \times 10^{12}$ & $4.56 \times 10^{12}$ & $6.95 \times 10^{12}$ & $8.19 \times 10^{5}$ & $1.07 \times 10^{6}$ & 31.60 & 34.3 \\
\hline
\end{tabular}


Table 13. Summarized 6E Analysis of Base Qom power plant and Hybridized plant.

\begin{tabular}{ccccccc}
\hline Parameter & With solar field & Without solar field & $\begin{array}{c}\text { \% Increase or } \\
\text { Decrease }\end{array}$ & $\begin{array}{c}\text { Parameter per Net } \\
\text { Power (Hybridized) }\end{array}$ & $\begin{array}{c}\text { Parameter per Net } \\
\text { Power (Base) }\end{array}$ & $\begin{array}{c}\text { \% Increase or } \\
\text { decrease (per net } \\
\text { power) }\end{array}$ \\
\hline $\begin{array}{c}\text { Gas cycle output } \\
\text { power (MW) }\end{array}$ & 516.24 & 516.24 & 0.0 & - & - & - \\
$\begin{array}{c}\text { Steam cycle output } \\
\text { power (MW) }\end{array}$ & 212.69 & 198.51 & 7.14 & - & - & - \\
$\begin{array}{c}\text { Electrical } \\
\text { efficiency (\%) }\end{array}$ & 47.00 & 45.00 & 4.44 & - & - & - \\
$\dot{C}_{k}+\dot{Z}_{D, k}$ (tot) & $11,559.77$ & $10,389.6$ & 11.26 & 15.87 & 14.55 & 9.07 \\
$\dot{B}_{k}+\dot{Y}_{D, k}$ (tot) & $1,916,819$ & $1,885,317$ & 1.67 & 2632.99 & 2640.5 & -0.28 \\
$\dot{Z}_{k}$ (tot) (MW) & 254.57 & 237.45 & 7.2 & 0.34 & 0.33 & 3.03 \\
$\dot{V}_{k}+\dot{N}_{D, k}$ (tot) & $5.24 \times 10^{16}$ & $4.93 \times 10^{16}$ & 6.2 & $7.19 \times 10^{13}$ & $6.9 \times 10^{13}$ & 14.49 \\
$\dot{U}_{k}+\dot{M}_{D, k}$ & $9.50 \times 10^{15}$ & $8.23 \times 10^{15}$ & 15.4 & $1.3 \times 10^{13}$ & $1.15 \times 10^{13}$ & 13.04 \\
\hline
\end{tabular}

\section{Conclusion}

In this paper, energy, exergy, exergoeconomic, exergoenvironmental, emergoeconomic, and emergoenvironmental (6E) analysis of Qom combined cycle and integrated solar PTC with Qom combined cycle power plant has been performed. In this regard, validation of the thermodynamic results of developed MATLAB code has been compared with Thermoflex software and plant data with acceptable accuracy.

Table 13 shows the summarized $6 \mathrm{E}$ analysis of the base case and hybridized plant.

Summary of the conclusion of adding a solar system to Qom Combined Cycle Power Plan.

1. With the solar system's integration into the Qom Combined Cycle Power Plant, the plant's capacity increased from $714 \mathrm{MW}$ to $728 \mathrm{MW}$.

2. The price of electricity is reduced compared to the base case. Although the initial cost of using a solar system is high, it reduces the cost of electricity consumed in many types of equipment, including steam turbines and heat exchangers.

3. The environmental impacts in equipment such as high-pressure evaporators and high-pressure superheaters are reduced, protecting the environment.

4. In the integrated system, the equipment (Z) 's initial cost has increased a lot, which is due to the high cost of solar collectors and its addition to the cycle. But then it costs a few years.

5. In the proposed case does not change the emission of pollutants much.

6. The inlet flow to the evaporator is reduced, and consequently, the cost and pollutants produced by it are reduced. Still, another system (solar collectors and converters) is added to the cycle, which increases costs and emits pollutants.

7. With the addition of the solar system in the emergy analysis, it is observed that despite the solar system in the cycle, the amount of emergy is very small compared to other equipment.

\section{References}

[1] S. Ihm, O. Y. Al-Najdi, O. A. Hamed, G. Jun, and H. Chung, "Energy cost comparison between MSF, MED and SWRO: Case studies for dual purpose plants," Desalination, vol. 397, pp. 116-125, 2016/11/01/ 2016.

[2] M. Salimi and M. Amidpour, "Total site cogeneration and desalination system integration assessment using
R-curve," Modares Mechanical Engineering, vol. 17, pp. 227-238, 04/18 2017.

[3] S. R. Hosseini, M. Amidpour, and S. E. Shakib, "Cost optimization of a combined power and water desalination plant with exergetic, environment and reliability consideration," Desalination, vol. 285, pp. 123-130, 2012/01/31/ 2012.

[4] R. Ahmadi, M. Pourfatemi, and S. Ghafari, "Exergoeconomic optimization of hybrid system of GT, SOFC and MED implementing genetic algorithm," Desalination, vol. 411, pp. 76-88, 06/01 2017.

[5] M. Hosseini, I. Dincer, P. Ahmadi, H. Barzegaravval, and M. Ziabasharhagh, "Thermodynamic modelling of an integrated solid oxide fuel cell and micro gas turbine system for desalination purposes," International Journal of Energy Research, vol. 37, 04/01 2013.

[6] B. Najafi, A. Shirazi, M. Aminyavari, F. Rinaldi, and R. A. Taylor, "Exergetic, economic and environmental analyses and multi-objective optimization of an SOFC-gas turbine hybrid cycle coupled with an MSF desalination system," Desalination, vol. 334, no. 1, pp. 46-59, 2014/02/03/ 2014.

[7] R. Chacartegui, D. Sánchez, N. di Gregorio, F. J. Aguilar, A. Muñoz Blanco, and T. Sanchez, "Feasibility analysis of a MED desalination plant in a combined cycle based cogeneration facility," Applied Thermal Engineering, vol. 29, pp. 412-417, 02/01 2009.

[8] C. li, D. Goswami, A. Shapiro, E. K. Stefanakos, and G. Demirkaya, "A new combined power and desalination system driven by low grade heat for concentrated brine," Energy, vol. 46, pp. 582-595, 10/01 2012.

[9] M. Deymi-Dashtebayaz and P. Kazemiani, "Energy, Exergy, Economic, and Environmental analysis for various inlet air cooling methods on Shahid HashemiNezhad gas turbines refinery," Energy \& Environment, p. 0958305X1879311, 08/15 2018.

[10] A. Abdalisousan, M. Fani, B. Farhanieh, and M. Abbaspour, "Effect of Decision Variables in the Steam Section for the Exergoeconomic Analysis of TCCGT Power Plant: A Case Study," Energy \& Environment, vol. 25, pp. 1381-1404, 11/01 2014.

[11] Z. Zhang, "Techno-Economic Assessment of Carbon Capture and Storage Facilities Coupled to Coal-Fired 
Power Plants *," Energy \& Environment, vol. 26, 12/01 2015.

[12] H.-W. Chiang, P.-Y. Wang, and H.-L. Li, "Combined Cycle Power Augmentation by Overspray Inlet Fogging," Journal of Energy Engineering-asce - J ENERG ENG-ASCE, vol. 136, 03/01 2010.

[13] S. Khanmohammadi and A. R. Azimian, "Exergoeconomic Evaluation of a Two-Pressure Level Fired Combined-Cycle Power Plant," Journal of Energy Engineering, vol. 141, p. 04014014, 10/07 2013.

[14] R. Lugo-Leyte, M. Salazar-Pereyra, A. E BonillaBlancas, H. Lugo Méndez, O. A Ruíz-Ramírez, and M. Toledo-Velázquez, "Exergetic Analysis of TripleLevel Pressure Combined Power Plant with Supplementary Firing," Journal of Energy Engineering, vol. 142, 02/25 2016.

[15] F. Calise, M. D. d'Accadia, L. Libertini, and M. Vicidomini, "Thermoeconomic analysis of an integrated solar combined cycle power plant," Energy Conversion and Management, vol. 171, pp. 10381051, 2018/09/01/ 2018.

[16] A. Baghernejad and M. Yaghoubi, "Exergoeconomic analysis and optimization of an Integrated Solar Combined Cycle System (ISCCS) using genetic algorithm," Energy Conversion and Management, vol. 52, no. 5, pp. 2193-2203, 2011/05/01/ 2011.

[17] K. Bahlouli, "Multi-objective optimization of a combined cycle using exergetic and exergoeconomic approaches," Energy Conversion and Management, vol. 171, pp. 1761-1772, 2018/09/01/ 2018.

[18] E. J. C. Cavalcanti, "Exergoeconomic and exergoenvironmental analyses of an integrated solar combined cycle system," Renewable and Sustainable Energy Reviews, vol. 67, pp. 507-519, 2017.

[19] L. Achour, M. Bouharkat, and O. Behar, "Performance assessment of an integrated solar combined cycle in the southern of Algeria," Energy Reports, vol. 4, pp. 207-217, 2018/11/01/ 2018.

[20] M. Amelio, V. Ferraro, V. Marinelli, and A. Summaria, "An evaluation of the performance of an integrated solar combined cycle plant provided with air-linear parabolic collectors," Energy, vol. 69, pp. 742-748, 2014/05/01/ 2014.

[21] M. Alibaba, R. Pourdarbani, M. H. K. Manesh, G. V. Ochoa, and J. D. Forero, "Thermodynamic, exergoeconomic and exergo-environmental analysis of hybrid geothermal-solar power plant based on ORC cycle using emergy concept," Heliyon, vol. 6, no. 4, p. e03758, 2020.

[22] B. Ghorbani and S. M. Ebadi, "Economic evaluation of saline water desalination system in Qeshm Island using using flat plate solar collectors and phase change material," Iranian journal of Ecohydrology, vol. 7, no. 4, pp. 891-906, 2020.

[23] M. K. M. Esmaeilzadehazimi, Mohammad Hasan \& Heleyleh, B. \& Modabber, Hossein, "4E Analysis of Integrated MHD-Combined Cycle," International Journal of Thermodynamics, vol. 22, pp. 219-228, 2019.
[24] M. H. Khoshgoftar Manesh, S. Kabiri, M. Yazdi, and F. Petrakopoulou, "Thermodynamic evaluation of a combined-cycle power plant with MSF and MED desalination," Journal of Water Reuse and Desalination, vol. 10, no. 2, pp. 146-157, 2020.

[25] M. Moradi, B. Ghorbani, R. Shirmohammadi, M. Mehrpooya, and M.-H. Hamedi, "Developing of an integrated hybrid power generation system combined with a multi-effect desalination unit," Sustainable Energy Technologies and Assessments, vol. 32, pp. 71-82, 2019.

[26] H. V. MODABBER and M. H. K. MANESH, "4E Analysis of Power and Water Cogeneration Plant based on Integrated MED-TVC and RO Desalination Units," International Journal of Thermodynamics, vol. 23, no. 2, pp. 107-126, 2020.

[27] M. H. R. Khoshgoftar Manesh, Marc, "Combined Cycle and Steam Gas-Fired Power Plant Analysis through Exergoeconomic and Extended Combined Pinch and Exergy Methods," Journal of Energy Engineering, vol. 144, 2018.

[28] C. Tzivanidis, E. Bellos, and K. A. Antonopoulos, "Energetic and financial investigation of a standalone solar-thermal Organic Rankine Cycle power plant," Energy conversion and management, vol. 126, pp. 421-433, 2016.

[29] E. Lüpfert et al., "Euro Trough collector qualification complete-performance test results from PSA," in ISES Solar World Congress 2001 \& 2003 Proceedings, 2003.

[30] A. Bejan, G. Tsatsaronis, and M. J. Moran, Thermal design and optimization. John Wiley \& Sons, 1995.

[31] I. Dincer and M. A. Rosen, Exergy: energy, environment and sustainable development. Newnes, 2012.

[32] H.-Y. Kwak, D.-J. Kim, and J.-S. Jeon, "Exergetic and thermoeconomic analyses of power plants," Energy, vol. 28, no. 4, pp. 343-360, 2003.

[33] M. H. K. Manesh and M. Amidpour, Cogeneration and Polygeneration Systems. Academic Press, 2020.

[34] H. Y. Kwak, D. J. Kim, and J. S. Jeon, "Exergetic and thermoeconomic analyses of power plants," Energy, vol. 28, no. 4, pp. 343-360, 3// 2003.

[35] L. Meyer, G. Tsatsaronis, J. Buchgeister, and L. Schebek, "Exergoenvironmental analysis for evaluation of the environmental impact of energy conversion systems," Energy, vol. 34, no. 1, pp. 7589, 2009/01/01/ 2009.

[36] S. Bastianoni, A. Facchini, L. Susani, and E. Tiezzi, "Emergy as a function of exergy," Energy, vol. 32, no. 7, pp. 1158-1162, 2007.

[37] A. Lazzaretto and G. Tsatsaronis, "SPECO: a systematic and general methodology for calculating efficiencies and costs in thermal systems," Energy, vol. 31, no. 8-9, pp. 1257-1289, 2006.

[38] M. Aghbashlo and M. A. Rosen, "Consolidating exergoeconomic and exergoenvironmental analyses using the emergy concept for better understanding energy conversion systems," Journal of Cleaner Production, vol. 172, pp. 696-708, 2018/01/20/ 2018. 